NBER WORKING PAPER SERIES

\title{
INFORMATION TECHNOLOGY EXTERNALITIES: EMPIRICAL EVIDENCE FROM 42 U.S. INDUSTRIES
}

\author{
Sung-Bae Mun \\ M. Ishaq Nadiri \\ Working Paper 9272 \\ http://www.nber.org/papers/w9272 \\ NATIONAL BUREAU OF ECONOMIC RESEARCH \\ 1050 Massachusetts Avenue \\ Cambridge, MA 02138 \\ October 2002
}

We would like to thank William J. Baumol, Hyunbae Chun, Boyan Jovanovic, and Edward Wolff for their very helpful comments and Steve Rosenthal for providing the data used in this paper. The views expressed herein are those of the authors and not necessarily those of the National Bureau of Economic Research.

(C) 2002 by Sung-Bae Mun and M. Ishaq Nadiri. All rights reserved. Short sections of text, not to exceed two paragraphs, may be quoted without explicit permission provided that full credit, including $(\subset$ notice, is given to the source. 
Information Technology Externalities: Empirical Evidence from 42 U.S. Industries Sung-Bae Mun and M. Ishaq Nadiri

NBER Working Paper No. 9272

October 2002

JEL No. D24, O47

\section{$\underline{\text { ABSTRACT }}$}

Using interindustry transaction in input-output tables, we examine Information Technology (IT) externalities in U.S. private industries over the period 1984-2000. Our empirical results show that computerization of an industry's customer and supplier industries reduces both labor and material costs of the industry. Moreover, cost savings driven by supplier industries are larger than those driven by customer industries. We also find that industries in the services sector enjoy more benefits from IT spillovers than industries in other sectors because of their high IT capital intensity and composition of interindustry transaction. Decomposition of total factor productivity (TFP) suggests that IT externalities can explain considerable parts of TFP growth, although possible mismeasurement of output in services industries leads to exacerbated technical changes of services industries.

Sung-Bae Mun

Department of Economics

New York University

269 Mercer Street, 7th Floor

New York, NY 10003

sbm210@nyu.edu
M. Ishaq Nadiri

Department of Economics

New York University

269 Mercer Street, 7th Floor

New York, NY 10003

and NBER

min1@nyu.edu 


\section{Introduction}

The rapid innovation in Information Technology (IT) over the past few decades has led to substantial changes in the U.S. economy. Modern economic activities are largely carried out with the help of IT. One characteristic of IT capital distinguishing itself from a traditional capital investment is its wide diffusion across industries and the broad range of its application. Manufacturing industries operate computer-integrated manufacturing system to link design, production, and management together for the efficient use of their resources. With the help of IT, many services are customized and are provided just in time. There are many other areas of IT application, such as management of inventories and human resources, accurate decision making based on instant market data, effective control of supply chain, and so on.

With advanced communication technology, IT enhances the sphere of its application even further. IT and communication technology make it possible for firms to interact with others in a faster and more efficient way. ${ }^{1}$ The network effect of IT has been emphasized as one of the key factors for assessing the value of IT by many researchers (Bresnahan, 2001; Brynjolfsson and Hitt, 2000; Inoue, 1998). The IT network not only facilitates communication between firms but also helps to streamline their production processes and lower transaction costs. Therefore, another feature of IT capital that distinguishes it from other traditional inputs is that IT capital may generate considerable economic externalities.

A network externality exists when the efficiency of products or services increases as products or services are adopted by more users. There are two types of network externality, direct and indirect network effects (Katz and Shapiro, 1985). The direct network effect comes from an increase in users, while the indirect effect comes from the development of applications.

\footnotetext{
${ }^{1}$ See Brynjolfsson and Hitt (2000) for case examples.
} 
Both direct and indirect network effects also have a significant influence on the diffusion and usage of IT.

There are some studies which empirically investigate whether a product exhibits network externalities. Gandal (1994), for example, tested the existence of network externalities in the computer spreadsheets market. He showed that consumers are willing to pay more for a spreadsheet which is compatible with others. Brynjofsson and Kemerer (1996) also analyzed the microcomputer spreadsheet market using a hedonic model to determine the effect of network externalities. They found that the size of a product's installed base, a key factor in network externalities, indeed significantly affects the price of the product.

In addition to network externalities associated with IT, we may think of another type of externalities of IT, the so called knowledge spillovers (learning effect). The adoption of IT deeply involves innovations in the production process and organizational changes (Brynjolfsson and Hitt, 2000). The knowledge that enables a firm or an industry to adopt advanced technology successfully will naturally spill over to other firms or industries (Romer, 1986).

The one key element in both network and learning effects is interaction among IT users. For the production sector, the interaction among agents can be observed as a transaction between firms or industries. For example, Economides (1996) stressed that vertical relations among firms can play a critical role in network and learning effects. In a similar vein, assessing IT externalities between industries, we need to take into account the industrial interdependence characterized by interindustry transaction.

In this paper, we construct IT spillover stocks available to an industry that are a weighted sum of IT capital stock of other industries using weight equal to interindustry transaction. In doing so, we distinguish the IT spillover stocks into two kinds: one from intermediate inputs 
supplier industries and the other from customer industries. Then, we estimate a variable cost function with the IT spillover stocks using the data on 42 U.S. private industries from 1984 to 2000. The results show that the IT spillover stocks reduce variable costs of all industries. Furthermore, IT externalities driven by intermediate input suppliers are larger and more significant than IT externalities driven by customers. Comparing industries, we find that benefits of IT spillovers are greater in the services industries than in other industries not only because of their high IT capital intensity but also because of their transaction patterns. In the analysis of the long-run effect of the IT spillover stocks, we find that the demand for own IT capital of an industry is significantly affected by the IT demand of customer and supplier industries. Finally, our decomposition of total factor productivity (TFP) growth suggests that the IT spillover effects can explain considerable parts of the measured TFP growth.

The rest of the paper is organized as follows. Section 2 constructs the IT spillover stocks. Section 3 explains the empirical framework. Section 4 describes the data. Section 5 presents estimation results and section 6 concludes the paper.

\section{Measurement of IT Spillover Stock}

Constructing IT spillover stocks incorporating linkages among industries, we use an interindustry transaction matrix in input-output tables. The interindustry transactions can be divided into intermediate input demand from other industries and output supply to other industries which, are also referred to as backward and forward linkages, respectively (Hirschman, 1958). ${ }^{2}$ For example, the intermediate input purchase of industry $A$ from industry $B$ is the backward linkage of industry $A$, while industry $A$ 's sales of its output to industry $C$ is the forward

\footnotetext{
${ }^{2}$ Terleckyj (1974) and Wolff and Nadiri (1993) also use the interindustry flow matrix to examine the effect of R\&D spillovers on productivity growth.
} 
linkage of industry $A$. Therefore, industry $B$ and $C$ are an intermediate input supplier and customer industries of industry $A$, respectively.

Since there is no reason to assume from the backward and forward linkages of an industry that IT spillovers are the same, we construct two types of IT spillover stocks, $S O_{B}$ and $S O_{F} . S O_{B}$ represents the IT spillover stock available through intermediate input supplier industries (backward linkages), while $S O_{F}$ represents the IT spillover stock available through customer industries (forward linkages). We assume that the IT spillover stock from industry $j$ to industry $i$ increases as industry $j$ supplies its product relatively more than other industries do to industry $i$. Then, the IT spillover stock of industry $i$ through intermediate input supplier industries is given by:

$$
S O_{B}^{i}=\sum_{j \neq i} \frac{a^{i j}}{x^{i}} K_{O}^{j},
$$

where $a^{i j}$ is the value of industry $i$ 's intermediate input purchased from industry $j, x^{i}$ is the total value of industry $i$ 's interindustry transaction including both demand and supply transactions, and $K_{O}^{j}$ is the IT capital stock owned by industry $j$. Therefore, $S O_{B}^{i}$ depends not only on the size of other industries' IT capital stocks but also on the transaction matrix of industry $i$. In the extreme case, if industry $i$ does not need any intermediate input from industry $j$, then the IT spillover from industry $j$ will be zero no matter how large the IT stock of industry $j$ is.

Similarly, we construct IT spillover stock available through an industry's customer industries. Assuming that the size of IT spillover from industry $j$ to $i$ increases as industry $j$ 
purchases the product of industry $i$ relatively more than other industries do, the IT spillover stock for industry $i$ through customer industries is given by:

$$
S O_{F}^{i}=\sum_{j \neq i} \frac{b^{i j}}{x^{i}} K_{O}^{j}
$$

where $b^{i j}$ is the value of industry $i$ 's sales to industry $j .{ }^{3}$ Therefore, the IT spillover stocks, $S O_{B}$ and $S O_{F}$, provide us two different sources of IT externalities. ${ }^{4} \mathrm{SO}_{B}$ will capture the IT externality from computerization of supplier industries, while $S O_{F}$ will grasp the IT externality from computerization of customer industries.

Table 1 presents each industry's own IT capital stock $\left(K_{O}\right)$ and two IT spillover stocks $\left(S O_{B}\right.$ and $S O_{F}$ ) in 1984 and in 2000. From the first and the second column, the own IT capital stocks increased very rapidly for all industries from 1984 to 2000. Roughly speaking, the own IT capital stocks in 2000 are about 9-10 times larger than those in 1984 for all industries. Examining the own IT capital stocks across industries, we can notice that services industries, such as wholesale trade, bank and security, and business services, are the major IT using industries. In fact, the IT capital stocks of services industries can explain most of total IT capital stock in the U.S. private economy. Since our IT spillover stocks are weighted by transaction flow between industries, the concentration of IT capital in services industries implies that industries which transact more with service industries have larger IT spillover stocks. Within the

\footnotetext{
${ }^{3}$ To avoid double counting the IT spillover stocks, we use the total value of transactions (demand and supply) as the denominator in weights for both $S O_{B}$ and $S O_{F}$. Therefore, the sum of $\sum_{j \neq i} \frac{a^{i j}}{x^{i}}$ and $\sum_{j \neq i} \frac{b^{i j}}{x^{i}}$ is equal to one.

${ }^{4}$ We will omit industry superscript for simplicity from this point.
} 
manufacturing sector, industrial machinery and equipment and electronic and other electric equipment use relatively more IT capital than other manufacturing industries.

\section{[Table 1]}

Columns 3 to 6 in Table 1 present the IT spillover stocks from the backward linkage $\left(S O_{B}\right)$ and the forward linkage ( $S O_{F}$ ) of industries constructed by equations (1) and (2). Due to the fast growth of IT capital stocks in all industries, the IT spillover stocks also grew rapidly. Comparing $S O_{B}$ and $S O_{F}$ in 2000, we come up with some interesting findings. First, thirty two out of forty two industries have larger $S O_{B}$ than $S O_{F}$. This difference comes from both the proportion of intermediate input demand in total interindustry transaction and how much an industry transacts with IT-intensive industries, particularly with services industries. Second, $S O_{F}$ is generally smaller in manufacturing industries than in services industries, while $S O_{B}$ shows little difference between manufacturing and services industries. Unlike backward linkages, forward linkages of manufacturing industries are not as diversified as those of service industries. For example, more than 50 percent of the interindustry sale of furniture and fixtures industry are demanded by the construction industry. Since the construction industry is one of less ITintensive industries, $S O_{F}$ for furniture and fixtures becomes small.

Given our observation of the distribution of IT capital stocks across industries, it is worthwhile to explore patterns of interindustry transaction, which result in differences of IT spillover stocks across industries. Table 2 shows the composition of each industry's transaction 
with three sectors: primary and construction, manufacturing, and the services sector. ${ }^{5}$ For example, four percent of the total transaction in the agriculture, forestry, and fishing industry is explained by transaction with industries in the primary and construction sector, 72 percent with industries in the manufacturing sector, and 24 percent with industries in the services sector. Comparing compositions of interindustry transaction in 1984 and in 1996, the composition of each industry's transaction has changed little over the period, although a proportion of transaction with the services industries slightly increased for most of industries. We also find that a large part of industrial transaction is carried out with industries within the same sector. Figure 1, which graphs columns 4 to 6 in Table 2, clearly illustrates this transaction pattern. Starting from the transportation industry, most transactions of the services industries are explained by transactions within the services sector. These transaction patterns, together with IT-intensiveness of services industries, suggest that if IT externalities exist through interindustry transaction, services industries will experience relatively a large impact of IT externalities.

[Table 2] and [Figure 1]

\section{Empirical Framework}

Assuming capital inputs are quasi-fixed at time period $t$, an industry's average variable cost function with exogenously given IT spillover stocks are written as

\footnotetext{
${ }^{5}$ The primary and construction sector includes agriculture, forestry, and fishing, mining, and construction industries.
} 


$$
\frac{C_{t}^{v}}{y_{t}}=C^{v}\left(P_{t}, K_{t}, S O_{t-1}, y_{t}, T\right) / y_{t},
$$

where $C_{t}^{v}$ is a variable cost at time $t, y_{t}$ is gross output, $P_{t}$ is a vector of variable input prices, $K_{t}$ is a vector of quasi-fixed inputs, $S O_{t-1}$ is a vector of IT spillover stocks, and $T$ is an index indicating the level of technology. We assume labor $(L)$ and intermediate input $(M)$ as variable inputs and non-IT capital $\left(K_{N}\right)$ and IT capital $\left(K_{O}\right)$ as quasi-fixed inputs.

To analyze the effect of IT spillover stocks on the structure of the average variable cost in detail, we employ a restricted symmetric generalized McFadden cost function used in Bernstein (2000). Incorporating quasi-fixed inputs, Bernstein modified a symmetric generalized McFadden cost function introduced by Diewert and Wales (1987). Imposing homotheticity of the variable cost function in output, we have a following average variable cost function.

$$
\begin{aligned}
c_{t}^{v}= & \frac{C_{t}^{v}}{y_{t}}=\left[\sum_{i} \alpha_{i} p_{i, t}+\frac{1}{2} \sum_{i} \sum_{j} \alpha_{i j} p_{i, t} p_{j, t} W_{t}^{-1}+\sum_{i} \sum_{h} \alpha_{i h} p_{i, t} S O_{h, t-1}+\sum_{i} \alpha_{i T} p_{i, t} T_{t}\right] y_{t}^{\eta-1} \\
& +\left[\sum_{l} \beta_{l} k_{l, t}+\frac{1}{2} \sum_{l} \sum_{m} \beta_{l m} k_{l, t} k_{m, t} y_{t}^{1-\eta}+\sum_{l} \sum_{h} \beta_{l h} k_{l, t} S O_{h, t-1}+\sum_{l} \beta_{l T} k_{l, t} T_{t}\right] W_{t}, \\
i, j= & L, M, \quad h=B, F, \quad l, m=N, O,
\end{aligned}
$$

where $p_{i, t}$ is the price of variable input $i$ at time $t, k_{l, t}$ is the intensity of quasi-fixed input $l$ $\left(\frac{K_{l, t}}{y_{t}}\right), S O_{h, t-1}$ is the IT spillover stock, $T_{t}$ is time trend, and $W_{t}$ is $\sum_{i} \theta_{i} p_{i t}$ where $\theta_{i}$ is a predetermined coefficient. The parameters to be estimated are $\alpha_{i}, \alpha_{i j}, a_{i h}, a_{i T}, \beta_{l}, \beta_{l m}, \beta_{l h}, \beta_{l T}$, and $\eta$. 
Differentiating the average variable cost function in equation (4) with respect to variable input prices and using Shephard's lemma, we have the following variable input intensity equations:

$$
\begin{aligned}
v_{i, t}= & \frac{q_{i, t}}{y_{t}}=\left[\alpha_{i}+\sum_{j} \alpha_{i j} p_{j, t} W_{t}^{-1}-\frac{1}{2} \theta_{i} \sum_{i} \sum_{j} \alpha_{i j} p_{i, t} p_{j, t} W_{t}^{-2}+\sum_{h} \alpha_{i h} S O_{h, t-1}+\alpha_{i T} T_{t}\right] y_{t}^{\eta-1} \\
& +\theta_{i}\left[\sum_{l} \beta_{l} k_{l, t}+\frac{1}{2} \sum_{l} \sum_{m} \beta_{l m} k_{l, t} k_{m, t} y_{t}^{1-\eta}+\sum_{l} \sum_{h} \beta_{l h} k_{l, t} S O_{h, t-1}+\sum_{l} \beta_{l T} k_{l, t} T_{t}\right],
\end{aligned}
$$

where $q_{i, t}$ is the quantity of variable input $i$ at time $t$. The intensity of variable input $\left(v_{i, t}\right)$ depends on variable input prices $\left(p_{i, t}\right)$, the industry's output $\left(y_{t}\right)$, the time trend $\left(T_{t}\right)$, the intensity of quasi-fixed inputs $\left(k_{l, t}\right)$, and the IT spillover stocks $\left(S O_{h, t-1}\right)$.

In addition to the system of variable input intensity equations, information about the quasi-fixed input is also used in the estimation. In the long-run equilibrium, shadow prices of quasi-fixed inputs are equal to rental prices of capital. Therefore, differentiating the average cost function with respect to capital input intensities, we have

$$
\frac{\partial c_{t}^{v}}{\partial k_{l, t}}=-w_{K_{l}, t}=W_{t}\left[\beta_{l}+\sum_{m} \beta_{l m} k_{m, t} y_{t}^{1-\eta}+\sum_{h} \beta_{l h} S O_{h, t-1}+\beta_{l T} T_{t}\right]
$$

where $w_{K_{l}, t}$ is the rental price for $K_{l}$ at time $t$. Using equation (6), we can solve for capital input intensities as: 


$$
\begin{aligned}
& k_{l, t}=\left(\beta_{m m} D_{l, t}-\beta_{l m} D_{m, t}\right) /\left(\beta_{l l} \beta_{m m}-\beta_{l m}^{2}\right), \\
& D_{l, t}=-\left[\beta_{l}+\sum_{h} \beta_{l h} S O_{h, t-1}+\beta_{l T} T_{t}+w_{K_{l}, t} W_{t}^{-1}\right] y_{t}^{\eta-1}, \\
& l, m=N, O .
\end{aligned}
$$

The intensities of quasi-fixed inputs depend on variable input prices, the industry's output, the time trend, rental prices of the quasi-fixed inputs, and IT spillover stocks. Equations (5) and (7) define the system of equations to be estimated.

\section{Data}

The study covers 42 U.S. private industries over the period of 1984-2000. The data used in the study are obtained from several sources. The nominal values and chain-type price indexes of gross output and intermediate inputs are obtained from the Gross Product Originating (GPO) published by the Bureau of Economic Analysis (BEA). The number of full time equivalent employees is used as the quantity of labor. The wage index is constructed by dividing compensation of employees by the number of full time equivalent employees. For capital stock, we obtained investment data for 61 different types of assets from the Fixed Reproducible Tangible Wealth (FRTW) provided by the BEA. Using the detailed investment series, we construct capital stock using a perpetual inventory method with geometric depreciation rate from Fraumeni (1997).

The rental price for each asset is estimated by $w_{k, t}=\frac{\left(1-i t c_{k, t}-z_{k, t} u_{t}\right)}{1-u_{t}}\left(r_{t}+\delta_{k}-\pi_{k, t}\right) p_{k, t}$, where itc $_{k, t}$ is the investment tax credit for asset $k$ at time period $t, u$ is the corporate income tax rate, $z$ is the present value of capital consumption allowance, $r$ is the nominal rate of return, $\delta_{k}$ is 
the depreciation rate, $\pi_{k}$ is the asset specific capital gain, and $p_{k, t}$ is the investment deflator. All tax related variables are obtained from the Bureau of Labor Statistics (BLS). We use Moody's Aaa corporate bond yield rate for the nominal rate of return and set the capital gains to zero.

Using the Törnqvist index method, 61 types of assets for each industry are aggregated into two types of capital, IT and non-IT capital stocks. IT capital stock consists of mainframe computers, personal computers, direct access storage devices, computer printers, computer terminals, computer tape drives, computer storage devices, other office equipment, and software. ${ }^{6}$ Non-IT capital stock is constructed by aggregating other non-IT equipment and structures.

The value of interindustry intermediate input demand and supply are obtained from the input-output table prepared by the Office of Employment Projections (OEP) at the BLS. The OEP developed annual input-output tables for 192 industries for the years 1983 through 2000. The use table in the input-output data set shows the purchase of commodities by each industry as inputs into its production process. Aggregating the columns and rows of the use table into 42 industries, we obtain matrix A which shows the transaction of intermediate goods between 42 industries. The diagonal of matrix A is set to zero in order to eliminate intraindustry transaction. Defining $\mathrm{X}$ as equal to $\mathrm{A}+\mathrm{B}$ where $\mathrm{B}$ is the transpose of $\mathrm{A}$, we obtain total interindustry transaction matrix $\mathrm{X}$. The sum of each column in $\mathrm{X}$ represents the total value of interindustry transaction of the industry in each column. Finally, dividing each column of matrix A by the total value of interindustry transaction of each industry, we obtain the backward linkages of industries. Similarly, dividing each column of matrix B by the total value of interindustry transaction, we obtain the forward linkages of industries.

\footnotetext{
${ }^{6}$ Software consists of prepackaged software, custom software, and own-account software.
} 


\section{Estimation Result}

We jointly estimate equations (5) and (7) using the seemingly unrelated regression (SUR) method. The predetermined parameters, $\theta_{L}$ and $\theta_{M}$, are set to be average variable cost shares of labor and intermediate input, respectively. The industry dummy variables are introduced in the first order parameters, $\alpha_{i}$ and $\beta_{l}$. For possible serial correlation in errors, we assume the firstorder autocorrelation in the residuals of the system of equations. In the initial estimation, the concavity in variable input prices was satisfied, but the convexity in quasi-fixed inputs was not. After imposing the convexity restriction on the second order partial derivative matrix of the average variable cost function with respect to the intensities of quasi-fixed inputs, we estimate the system of variable and quasi-fixed input intensity equations. The parameter estimates are shown in Table 3.

[Table 3]

\section{IT Spillover Effect}

Using the parameter estimates in Table 3, we estimate the short-run and long-run elasticities with respect to IT spillover stocks. Differentiating the average variable cost in

equation (4) with respect to $S O_{B}$ and $S O_{F}$ and multiplying $\frac{S O_{h}}{c^{v}}$, we can obtain short-run spillover elasticities of average variable cost. Omitting time subscripts for simplicity, we have 


$$
\begin{aligned}
\varepsilon_{c^{v} S O_{h}} & =\left[\sum_{i} \alpha_{i h} p_{i} y^{\eta-1}+\sum_{l} \beta_{l h} k_{l} W\right] \frac{S O_{h}}{c^{v}}, \\
h & =B, F .
\end{aligned}
$$

where $\varepsilon_{c^{v} S O_{h}}$ shows percentage changes of average variable cost with one percent increase in $S O_{B}$ and $S O_{F}$, respectively. We can also drive short-run spillover elasticities of variable input intensities by differentiating the variable input intensity in equation (5) with respect to $S O_{B}$ and $S O_{F}$ and multiplying $\frac{S O_{h}}{v_{i}}$. These elasticities are

$$
\begin{aligned}
\varepsilon_{v_{i} S O_{h}} & =\left[\alpha_{i h} y^{\eta-1}+\theta_{i} \sum_{l} \beta_{l h} k_{l h}\right] \frac{S O_{h}}{v_{i}}, \\
i & =L, M .
\end{aligned}
$$

where $\varepsilon_{v_{i} S O_{h}}$ enables us to identify the channel of cost saving induced by the IT spillover stocks.

Table 4 shows mean the values of short-run elasticities of the average variable cost, labor, and material intensities with respect to $S_{B}$ and $S O_{F}$. The standard errors for elasticities are evaluated at the base year using the delta method.

\section{[Table 4]}

Negative values of both $\varepsilon_{c^{v} S O_{B}}$ and $\varepsilon_{c^{v} S O_{F}}$ in the first and second columns of Table 4 suggest that IT spillover stocks through intermediate input demand and supply reduce average variable costs of all industries. In other words, computerization of an industry's supplier and 
customer reduces the average cost of the industry. Relative magnitudes of $\varepsilon_{c^{v} S O_{B}}$ and $\varepsilon_{c^{v} S O_{F}}$ imply that the IT spillover stocks, through backward and forward linkages, have different effects on the average cost of an industry. Thirty-three industries out of 42 industries receive more benefit from the IT capital of intermediate input supplier industries $\left(S O_{B}\right)$ than from the IT capital of customer industries $\left(\mathrm{SO}_{F}\right)$. On the other hand, industries such as business services, legal services, wholesale trade, and bank and security enjoy average cost saving more from the IT capital of customer industries.

These different effects of $S O_{B}$ and $S O_{F}$ explain how the technological opportunities of IT can be different in the backward and forward linkages of an industry. Our results suggest that it is easier for most industries to capitalize computerization of intermediate input supplier industries. For example, the IT-based supply chain can enable industries to lower their materials inventory without interrupting their production processes. Meanwhile, cost saving effects of the IT spillover stock through the forward linkage are not apparent for all industries. However, it is interesting that industries receiving more benefits from $S O_{F}$ than from $S O_{B}$ not only have diversified forward linkages but also are IT-intensive industries in general. Diversified forward linkages imply that output produced by an industry is demanded not by a few specific industries but by many industries. Therefore, our results suggest that IT-intensive industries with diversified forward linkages, such as business services, legal services, wholesale trade, and bank and security, have more opportunities to take an advantage of IT capital of customer industries.

Comparing sectors, IT spillover stocks have much more impact on the services sector than the manufacturing sector. On average, a one percent increase in $S O_{B}\left(S O_{F}\right)$ reduces by $0.0076(0.0045)$ percent the average cost for the manufacturing sector and by $0.0228(0.0251)$ 
percent for the services sector. ${ }^{7}$ The results are consistent with our prediction. Given the fact that industries in the services sector own significant parts of the total IT capital stock in the economy, whether an industry receives benefits generated by the IT capital of service industries depends on how important service industries are as the industry's transaction partner. Since input-output tables indicate that the interindustry transaction can be mainly explained by transactions with industries within the same sector, IT externality caused by the IT capital of a services industry is mostly distributed to other services industries.

Columns 3 to 6 in Table 4 present the short-run spillover elasticities of labor and intermediate input intensities with respect to $S O_{B}$ and $S O_{F}$. Both labor and intermediate input intensities are reduced by $S O_{B}$ and $S O_{F}$ for all industries. For labor intensity in the manufacturing sector, the effect of $S O_{B}$ is stronger than that of $S O_{F}$. On average, a one percent increase in $S O_{B}$ reduces the labor intensity of manufacturing industries by 0.0121 percent. For the service industries, elasticities of labor and intermediate input intensities are roughly the same although intermediate input intensities decrease slightly more.

In the long run, the quasi-fixed inputs are no longer fixed. The IT and non-IT capital intensities are also affected by the IT spillover stocks. Therefore, we need to take into account the effects of $S O_{B}$ and $S O_{F}$ on the quasi-fixed inputs to evaluate the long-run effects of the spillover stocks. Differentiating the quasi-fixed input intensity in equation (7) with respect to IT spillover stocks and multiplying $\frac{S O_{h}}{k_{l}}$ gives us elasticities of the quasi-fixed input intensities,

\footnotetext{
${ }^{7}$ Estimates for sectors are the weighted averages of industries' estimates by the value of total cost.
} 


$$
\varepsilon_{k_{l} S O_{h}}^{l}=\left[\left(\beta_{l m} \beta_{m h}-\beta_{m m} \beta_{l h}\right) /\left(\beta_{l l} \beta_{m m}-\beta_{l m}^{2}\right)\right] \frac{S O_{h} y^{\eta-1}}{k_{l}} .
$$

The average variable cost elasticities with respect to quasi-fixed input intensities are

$$
\varepsilon_{c^{v} k_{l}}^{l}=\left[\beta_{l}+\sum_{m} \beta_{l m} k_{m} y^{1-\eta}+\sum_{h} \beta_{l h} S O_{h}+\beta_{l T} T\right] W \frac{k_{l}}{c^{v}} .
$$

Combining equations (10) and (11), the long-run elasticities of average variable cost with respect to IT spillover stocks are estimated by

$$
\varepsilon_{c^{v} S O_{h}}^{l}=\varepsilon_{c^{v} S O_{h}}+\varepsilon_{c^{v} k_{N}}^{l} \varepsilon_{k_{N} S O_{h}}^{l}+\varepsilon_{c^{v} k_{O}}^{l} \varepsilon_{k_{O} S O_{h}}^{l}
$$

The long-run effect of IT spillover stocks on the average cost consists of two components. First, $\varepsilon_{c^{v} O_{h}}$ captures the direct effect of IT spillover stock on the average cost. Second, changes in the quasi-fixed input intensities, induced by IT spillover stocks, affect the average variable cost expressed as $\varepsilon_{c^{v} k_{N}}^{l} \varepsilon_{k_{N} S O_{h}}^{l}+\varepsilon_{c^{v} k_{O}}^{l} \varepsilon_{k_{O} S O_{h}}^{l}$.

The long-run elasticities of variable input intensities with respect to IT spillover stocks are derived in as similar a way as the long-run elasticities of the average cost are derived. First, the elasticities of the variable input intensities, with respect to quasi-fixed input intensities, are given by 


$$
\varepsilon_{v_{i} k_{l}}^{l}=\theta_{i}\left[\beta_{l}+\sum_{m} \beta_{l m} k_{m} y^{1-\eta}+\sum_{h} \beta_{l h} S O_{h}+\beta_{l T} T\right] \frac{k_{l}}{v_{i}} .
$$

With equations (10) and (13), the long-run elasticities of variable input intensities, with respect to IT spillover stocks, are calculated by

$$
\varepsilon_{v_{i} S O_{h}}^{l}=\varepsilon_{v_{i} S O_{h}}+\varepsilon_{v_{i} k_{N}}^{l} \varepsilon_{k_{N} S O_{h}}^{l}+\varepsilon_{v_{i} k_{O}}^{l} \varepsilon_{k_{O} S O_{h}}^{l}
$$

Here we also have a direct and an indirect effect of IT spillover stocks on the intensities of variable inputs. In the long-run, $S O_{B}$ and $S O_{F}$ affect the variable input intensities directly and also through the changes in the quasi-fixed inputs induced by the IT spillover stocks.

The first and second columns in Table 5 show mean values of the long-run elasticity of the average variable cost with respect to $S O_{B}$ and $S O_{F}$. On average, the long-run elasticities of variable cost with respect to $S O_{B}$ and $S O_{F}$ are -0.0213 and -0.0170 percent, respectively. Compared to the short-run elasticities, the effect of $S O_{B}$ on average cost becomes stronger in the long run. On the other hand, the long-run effect of $S O_{F}$ becomes small and insignificant except for some IT intensive industries such as industrial machinery and equipment, instruments and related products, wholesale trade, and bank and security. The reason for these differences in the long-run elasticities can be sought in the elasticities of IT and non-IT capital intensities with respect to $S O_{B}$ and $S O_{F}$ in columns 3 to 6 in Table 5. An increase in $S O_{B}$ raises both an industry's IT and non-IT capital intensities, which results in a strong effect of $S O_{B}$ on the average variable cost in the long run. On the other hand, an increase in $S O_{F}$ increases the IT 
intensity as $S O_{B}$ does, but lowers the intensity of non-IT capital, which leads to a smaller effect of $\mathrm{SO}_{F}$ in the long run.

We also find that an industry's own IT demand strongly links with the IT spillover stocks in the long run. Columns 5 and 6 in Table 5 show that more IT adoption of an industry's intermediate input supplier and customer facilitates the industry's IT adoption. In particular, the IT demand of an industry responds more to an increase in the IT capital of a customer industry than in the IT capital of a supplier industry. On average, a one percent increase in $S O_{B}$ increases an industry's IT demand by 0.3482 percent, while a one percent increase in $S O_{F}$ increases an industry's IT demand by 0.5974 percent.

Columns 7 to 10 in Table 5 present the average long-run spillover elasticities of variable input intensities. Both $S O_{B}$ and $S O_{F}$ reduce labor and intermediate input intensities in the long run. For manufacturing industries, labor intensities decline on average 0.0189 percent to a one percent increase in $S O_{B}$ and 0.0055 percent to a one percent increase in $S O_{F}$, while intermediate input intensities show relatively small reduction. For services industries, long-run effects of $S_{B}$ and $S O_{F}$ on variable input intensities are alike. $S O_{B}\left(S O_{F}\right)$ reduces the labor intensity by $0.0270(0.0277)$ percent and the intermediate input intensity by $0.0339(0.0353)$ percent for services industries.

\section{Industrial Interdependence and Rates of Return to the IT Spillover Stock}

We have examined the effects of the IT spillover stocks on the cost structures of industries. Since the IT spillover stock is the weighted average of other industries' IT capital 
stocks, we can construct a matrix which shows how the IT spillover stock of one industry affects the cost structure of another industry.

$$
\text { Given that } S O_{B}^{i}=\sum_{j \neq i} \varpi_{B}^{i j} K O^{j} \text { and } S O_{F}^{i}=\sum_{j \neq i} \varpi_{F}^{i j} K O^{j} \text {, where } \varpi_{B}^{i j}=\frac{a^{i j}}{x^{i}} \text { and } \varpi_{F}^{i j}=\frac{b^{i j}}{x^{i}} \text {, the }
$$

variable cost elasticity of industry $i$ with respect to the IT capital stock in industry $j$ is calculated by

$$
\varepsilon_{C^{v} K_{O}^{j}}=\varepsilon_{c^{v} S O_{B}} \frac{\varpi_{B}^{i j} K_{O}^{j}}{S O_{B}^{i}}+\varepsilon_{c^{v} S O_{F}} \frac{\varpi_{F}^{i j} K_{O}^{j}}{S O_{F}^{i}} .
$$

As we can see in equation (15), $\varepsilon_{C^{v} K_{O}^{j}}$ depends on the elasticities with respect to the IT spillover stocks and contributions of industry $j$ 's IT capital stock to the IT spillover stocks for industry $i$. We can also calculate the rate of return generated to industry $j$ 's IT capital in terms of industry i’s variable cost:

$$
\frac{\partial C^{v}}{\partial K_{O}^{j}} / p_{K_{O}}^{i}=\left\{\frac{\partial C^{v}}{\partial S O_{B}^{i}} \varpi_{B}^{i j}+\frac{\partial C^{v}}{\partial S O_{F}^{i}} \varpi_{F}^{i j}\right\} / p_{K_{O}}^{i}
$$

where $p_{K_{O}}^{i}$ is the IT investment deflator for industry $i$. Both equations (15) and (16) produce matrices of which an element in row $i$ and column $j$ shows the effects of industry $j$ 's IT capital to industry $i$. Table 6 and Table 7 present these matrices. These matrices explain not only how much the IT capital stock of an industry reduces the variable cost of other industries but also which industry generates the biggest benefit among the U.S. private industries. For example, the value in the fourth row and the first column of the Table 6 reports that the variable cost of 
lumber and wood products is reduced by 0.000044 percent with respect to a one percent increase in the IT capital stock of agriculture, forestry, and fishing. The first column in Table 6 says that the IT capital stock of agriculture, forestry, and fishing industry has relatively more effect on the variable cost of food and kindred products and real estate than on other industries. Table 6 also suggests that the IT capital stock of the industries such bank and security, business services, wholesale and retail trade, and real estate play a key role in reducing the variable cost of other industries.

Using the matrix for the rate of return in Table 7 , we can explore give and take relationships between industries. For example, industry $i$ receives benefits from the IT capital of its customer and supplier industries. On the other hand, industry $i$ 's IT capital itself generates some returns to its customer and supplier industries. The first column in Table 8 shows, on average, returns to an industry received from a one dollar increase in the capital stock of other industries. Industries such as bank and security, wholesale trade, and business services receive larger returns than other industries. Within the manufacturing sector, industrial machinery and equipment and electronic and other electric equipment seem to get more benefits. The common characteristics of these beneficiary industries is that they are intensive users of IT capital. This implies that the external return to an industry may depend on the industry's own IT capital. The second column in Table 8 shows returns that a one dollar increase in the IT capital stock of an industry generates to other industries on average. It seems that industries receiving large returns also generate large returns to other industries. The biggest benevolent industry is business services. Comparing the first and second columns, we can observe that some industries receive more than what they give to other industries. For instance, the return that bank and security receives is four times larger than what it gives to other industries. In general, industries which 
receive more returns than what their IT capital stocks generate to other industries are concentrated in the services sector, such as bank and security, wholesale trade, and communication.

\section{TFP Decomposition}

The conventional measure of TFP for a single output technology is defined as the ratio of output over the Divisia index of aggregate input. Thus, the growth rate of TFP is written as

$$
\begin{aligned}
& \frac{\dot{T F P}}{T F P}=\frac{\dot{y}}{y}-\sum_{i} \frac{p_{i} q_{i}}{C} \frac{\dot{q}_{i}}{q_{i}}-\sum_{l} \frac{w_{K_{l}} K_{l}}{C} \frac{\dot{K}_{l}}{K_{l}}, \\
& i=L, M, \quad l, m=N, O,
\end{aligned}
$$

where a dot over a variable is a derivative with respect to time, $q_{i}$ is a quantity of a variable input, and $C=\sum_{i} p_{i} q_{i}+\sum_{l} w_{K_{l}} K_{l}$ is total cost. ${ }^{8}$ Following the same method of decomposing TFP growth in Denny, Fuss, and Waverman (1981) and Bernstein and Nadiri (1993), we can decompose TFP growth into scale effects, IT externalities, and technical change. Totally differentiating the variable cost function, $C^{v}=C^{v}(P, K, S O, y, T)$, with respect to time, and dividing by $C$, we have

$$
\frac{\dot{C}^{v}}{C}=\sum_{i} \frac{\partial C^{v}}{\partial p_{i}} \frac{\dot{p}_{i}}{C}+\sum_{l} \frac{\partial C^{v}}{\partial K_{l}} \frac{\dot{K}_{l}}{C}+\sum_{l} \frac{\partial C^{v}}{\partial S O_{h}} \frac{\dot{S} O_{h}}{C}+\frac{\partial C^{v}}{\partial y} \frac{\dot{y}}{C}+\frac{\partial C^{v}}{\partial T} \frac{1}{C}
$$

\footnotetext{
${ }^{8}$ Under the assumptions of constant returns to scale in the production function and perfect competition, revenue share can be used.
} 
Using Shephard's lemma $\left(\frac{\partial C^{v}}{\partial p_{i}}=q_{i}\right.$ and $\left.\frac{\partial C^{v}}{\partial K_{l}}=-w_{K_{l}}\right)$, we can rewrite equation (18) into

$$
\frac{\dot{C}^{v}}{C}=\sum_{i} \frac{p_{i} q_{i}}{C} \frac{\dot{p}_{i}}{p_{i}}+\sum_{l} \frac{w_{K_{l}} K_{l}}{C} \frac{\dot{K}_{l}}{K_{l}}+\sum_{l} \frac{\partial C^{v}}{\partial S O_{h}} \frac{S O_{h}}{c} \frac{\dot{S O_{h}}}{S O_{h}}+\frac{\partial C^{v}}{\partial y} \frac{y}{c} \frac{\dot{y}}{y}+\frac{\partial C^{v}}{\partial T} \frac{1}{C}
$$

Totally differentiating $C^{v}=\sum_{i} p_{i} q_{i}$ with respect to time, and dividing by $C$, give us

$$
\frac{\dot{C^{v}}}{C}=\sum_{i} \frac{p_{i} q_{i}}{C} \frac{\dot{p}_{i}}{p_{i}}+\sum_{i} \frac{p_{i} q_{i}}{C} \frac{\dot{q_{i}}}{q_{i}}
$$

By substituting equation (20) into equation (19), we obtain

$$
\sum_{i} \frac{p_{i} q_{i}}{C} \frac{\dot{q}_{i}}{q_{i}}+\sum_{l} \frac{w_{K_{l}}}{C} \frac{\dot{K}_{l}}{K_{l}}=\sum_{l} \frac{\partial C^{v}}{\partial S O_{h}} \frac{\dot{S O}_{h}}{C}+\frac{\partial C^{v}}{\partial y} \frac{y}{c} \frac{\dot{y}}{y}+\frac{\partial C^{v}}{\partial T} \frac{1}{C}
$$

Then, by definition of TFP growth from equation (17) with equation (21), we can express conventional TFP growth by

$$
\frac{\dot{T F P}}{T F P}=\left(1-\frac{\partial C^{v}}{\partial y} \frac{y}{C}\right) \frac{\dot{y}}{y}+\sum_{l} \frac{\partial C^{v}}{\partial S O_{h}} \frac{S O_{h}}{C} \frac{\dot{S O}_{h}}{S O_{h}}+\frac{\partial C^{v}}{\partial T} \frac{1}{C}
$$


As we can see in equation (22), TFP growth is decomposed into three parts. The first term on the right side of equation (22) shows the scale effect. The second term shows external effects from the IT spillover stocks. The third term implies technical changes.

Table 9 shows TFP growth for 42 U.S. private industries over the period from 1985 to 2000. There are 23 industries which exhibit positive productivity growth during the period. It is also interesting that 12 out of 19 services industries show negative productivity growth. As Triplett and Bosworth (2000) pointed out, the mismeasurement of output seems to contribute to negative productivity growth in services industries.

Columns 2 to 5 in Table 9 correspond to scale effect, IT externality effects from $S O_{B}$ and $S O_{F}$, and residuals. ${ }^{9}$ For many industries, scale effects explain large portions of TFP growth. Roughly speaking, scale effects account for about 15 to 20 percent of TFP growth for manufacturing industries. Contribution from the IT spillover stocks to TFP growth is positive for all industries. Comparing effects of $S O_{B}$ and $S O_{F}$, contribution from $S O_{B}$ is greater than that from $S O_{F}$ for most industries. As we observed in the result for the elasticities with respect to $S O_{B}$ and $S O_{F}$, the IT spillover effect on TFP is relatively larger in the services industries than in other industries. However, residuals are exacerbated because of possible mismeasurement of output in services industries.

\section{Conclusion}

The purpose of this paper was to investigate IT externality through interindustry transaction among U.S. private industries. We generated two types of IT spillover stocks

\footnotetext{
${ }^{9}$ Residuals include technical changes.
} 
available to an industry through intermediate input demand and supply, respectively. The empirical results of this study indicate that IT spillover stocks have a significant impact on the cost and production structure of industries.

We find that IT spillover stocks reduce the variable cost of all industries through savings in both labor and materials. We also find that IT externalities through intermediate input supplier industries are much stronger than those through customer industries. Comparing industries, we discover that opportunity of IT spillover is larger for services industries, due to their high IT intensity and transaction composition, than for manufacturing industries. The analysis for the long-run effects of IT spillovers suggests that an increase in IT capital stocks of supplier and customer industries can be an important determinant of industrial IT demands. The study also shows that the rate of return to IT investment due to its spillover effect is considerable and varying across industries.

Finally, our TFP decomposition suggests that IT spillover can contribute to an industry's productivity growth. However, we observed that strong IT externality for services industries together with the problem of mismeasurement of their output could worsen the measured technical changes of services industries. 


\section{References}

Bernstein, Jeffrey I., "Canadian Manufacturing, U.S. R\&D Spillovers, and Communication Infrastructure," Review of Economics and Statistics, 82(4), November 2000, 608-15.

Bernstein, Jeffrey I. and M. Ishaq Nadiri, "Production, Financial Structure and Productivity Growth in U.S. Manufacturing,” NBER Working Paper No. 4309, March 1993.

Bresnahan, Timothy F., "Prospects for an Information Technology-Led Productivity Surge," in Adam Jaffe, Joshua Lerner, and Scott Stern, eds., Innovation Policy and the Economy, Vol. 2, Cambridge: MIT Press, 2001.

Brynjolfsson, Erik and Lorin M. Hitt, "Beyond Computation: Information Technology, Organizational Transformation and Business Performance," Journal of Economic Perspectives, 14(4), Fall 2000, 23-48.

Brynjolfsson, Erik and Chris F. Kemerer, "Network Externalities in Microcomputer Software: An Econometric Analysis of the Spreadsheet Market," Management Science, 42(12), December 1996, 1627-47.

Denny, Michael, Melvyn Fuss, and Leonard Waverman, "The Measurement and Interpretation of Total Factor Productivity in Regulated Industries, with an Application to Canadian Telecommunications," in Thomas G. Cowing and Rodney E. Stevenson, eds., Productivity Measurement in Regulated Industries, New York: Academic Press, 1981, 179-218.

Diewert, Walter E. and Terence. J. Wales, "Flexible Functional Forms and Global Curvature Conditions," Econometrica, 55(1), January 1987, 43-68.

Economides, Nicholas, "The Economics of Networks," International Journal of Industrial Organization, 14(6), October 1996, 673-99.

Fraumeni, Barbara, "The Measurement of Depreciation in the U.S. National Income and Product Accounts," Survey of Current Business, July 1997, 7-23. 
Gandal, Neil, "Hedonic Price Indexes for Spreadsheets and an Empirical Test for Network Externalities," Rand Journal of Economics, 25(1), Spring 1994, 160-70.

Hirschman, Albert O., Strategy of Economic Development, Yale University Press, New Haven, CT., 1958.

Inoue, Tetsuya, "Impact of Information Technology and Implications for Monetary Policy," Monetary and Economic Studies, 16(2), December 1998, 29-60.

Katz, Michael L. and Carl Shapiro, "Network Externalities, Competition, and Compatibility," American Economic Review, 75(3), June 1985, 424-40.

Romer, Paul M., "Increasing Returns and Long-Run Growth,” Journal of Political Economy, 94(5), October 1986, 1002-37.

Terleckyj, Nestor, Effects of R\&D on the Productivity Growth of Industries: An Exploratory Study, Washington, D.C.: National Planning Association, 1974.

Triplett, Jack E. and Barry P. Bosworth, "Productivity in the Service Sector," Brookings Economic Papers, January 2000.

Wolff., Edward N. and M. Ishaq Nadiri, "Spillover Effects, Linkage Structure, and Research and Development," Structural Change and Economic Dynamics, 4(2), December 1993, 315-31. 
Table 1. Own IT and IT Spillover Stocks: 42 U.S. Industries in 1984 and 2000

\begin{tabular}{|c|c|c|c|c|c|c|}
\hline Industry & $K_{O}^{1984}$ & $\bar{K}_{O}^{2000}$ & $S_{S O_{B}^{1984}}$ & $S^{2} O_{B}^{2000}$ & $S_{S O_{F}^{1984}}^{19}$ & $S O_{F}^{2000}$ \\
\hline Agriculture, forestry, and fishing & 38.33 & 1602.74 & 1144.83 & 12616.25 & 590.00 & 8868.71 \\
\hline Mining & 1459.32 & 5004.96 & 1411.47 & 23308.05 & 740.62 & 3745.31 \\
\hline Construction & 119.88 & 7138.66 & 2041.69 & 23402.65 & 619.12 & 9778.35 \\
\hline Lumber and wood products & 141.11 & 1011.66 & 1191.39 & 14212.65 & 460.68 & 8426.71 \\
\hline Furniture and fixtures & 99.08 & 907.03 & 2137.65 & 23468.15 & 176.94 & 2329.77 \\
\hline Stone, clay, and glass products & 390.18 & 1913.17 & 831.44 & 9827.20 & 429.59 & 6925.55 \\
\hline Primary metal industries & 579.64 & 1795.73 & 1132.92 & 14548.34 & 941.57 & 7325.56 \\
\hline Fabricated metal products & 478.90 & 4190.21 & 974.25 & 11246.00 & 722.25 & 7867.80 \\
\hline Industrial machinery and equipment & 3069.72 & 21856.13 & 2385.66 & 22552.87 & 682.99 & 11926.10 \\
\hline Electronic and other electric equipment & 2513.83 & 17140.83 & 1591.06 & 15936.64 & 1156.16 & 16624.51 \\
\hline Transportation equipment & 1479.52 & 7672.02 & 2661.02 & 28238.35 & 334.26 & 3247.59 \\
\hline Instruments and related products & 720.38 & 9413.36 & 2358.23 & 22213.79 & 856.31 & 8397.56 \\
\hline Miscellaneous manufacturing industries & 131.38 & 902.30 & 2654.13 & 25674.38 & 804.09 & 15087.99 \\
\hline Food and kindred products & 702.51 & 4703.20 & 1452.17 & 18056.98 & 961.65 & 9639.89 \\
\hline Tobacco products & 102.08 & 256.05 & 3491.65 & 46761.54 & 48.70 & 1541.88 \\
\hline Textile mill products & 183.31 & 1564.09 & 1002.51 & 13024.95 & 603.88 & 6526.81 \\
\hline Apparel and other textile products & 189.73 & 937.25 & 2218.41 & 21985.31 & 318.02 & 5400.19 \\
\hline Paper and allied products & 345.38 & 1960.48 & 1048.92 & 13248.89 & 1447.32 & 17961.14 \\
\hline Printing and publishing & 746.17 & 13633.18 & 1811.17 & 24923.82 & 2025.25 & 25476.71 \\
\hline Chemicals and allied products & 906.78 & 9488.78 & 1518.10 & 19962.35 & 473.59 & 5534.52 \\
\hline Petroleum and coal products & 252.83 & 475.24 & 1293.54 & 10563.02 & 661.03 & 8981.03 \\
\hline Rubber and miscellaneous plastics product & 209.92 & 2874.50 & 837.08 & 11043.47 & 1004.56 & 10679.67 \\
\hline Leather and leather products & 27.07 & 141.72 & 2133.84 & 16526.63 & 231.76 & 8844.30 \\
\hline Transportation & 382.30 & 13086.17 & 1200.91 & 18835.27 & 999.12 & 14666.78 \\
\hline Communication & 976.33 & 22886.72 & 1338.25 & 21762.58 & 2605.17 & 28200.64 \\
\hline Electric, gas, and sanitary services & 2093.05 & 11319.66 & 793.75 & 10733.67 & 1141.41 & 16328.01 \\
\hline Wholesale trade & 14746.20 & 122687.71 & 1075.00 & 17209.72 & 755.85 & 9486.33 \\
\hline Retail trade & 4926.50 & 41003.09 & 2425.63 & 33589.72 & 291.45 & 5718.98 \\
\hline Bank and security & 14724.29 & 160823.70 & 983.28 & 24752.84 & 1506.41 & 11811.76 \\
\hline Insurance & 2927.49 & 31355.62 & 2903.91 & 43784.56 & 707.07 & 17277.96 \\
\hline Real estate & 1357.82 & 36232.76 & 608.25 & 12182.22 & 2920.33 & 36490.29 \\
\hline Hotels and other lodging places & 241.04 & 2304.35 & 2268.82 & 25736.71 & 1091.21 & 18026.47 \\
\hline Personal services & 164.15 & 1570.40 & 2077.98 & 32779.76 & 783.14 & 7501.46 \\
\hline Business services & 6787.41 & 98718.38 & 527.31 & 8085.46 & 3235.05 & 34933.83 \\
\hline Auto repair, services, and parking & 344.85 & 2124.88 & 1149.07 & 20406.96 & 1621.49 & 18153.85 \\
\hline Miscellaneous repair services & 127.65 & 1275.98 & 660.98 & 8795.97 & 1969.80 & 25894.93 \\
\hline Motion pictures & 227.72 & 3593.01 & 2014.25 & 40183.98 & 937.94 & 12796.06 \\
\hline Amusement and recreation services & 210.79 & 1779.48 & 2267.88 & 35755.95 & 620.20 & 8739.57 \\
\hline Health services & 1038.47 & 12505.25 & 2668.11 & 41605.96 & 0.31 & 1.26 \\
\hline Legal services & 434.76 & 6876.14 & 870.38 & 14051.37 & 2402.90 & 33324.81 \\
\hline Educational services & 120.83 & 963.82 & 1693.51 & 44121.69 & 389.56 & 1533.81 \\
\hline Other services & 2204.12 & 27690.86 & 1433.55 & 22266.27 & 1614.43 & 24693.13 \\
\hline
\end{tabular}

Note: Capital stocks are measured in millions of 1996 dollars. $K_{O}^{1984}$ is the own IT capital stock of a industry in $1984.5 O_{B}^{1984}$ and $S O_{F}^{1984}$ represent the IT spillover stocks through backward linkage and forward linkage of the industry, respectively. 
Table 2. Composition of Interindustry Transaction: 42 U.S. Industries in 1984 and 1996

\begin{tabular}{|c|c|c|c|c|c|c|}
\hline \multirow[b]{2}{*}{ Industry } & \multicolumn{3}{|c|}{1984} & \multicolumn{3}{|c|}{1996} \\
\hline & $\begin{array}{l}\text { Primary and } \\
\text { Construction }\end{array}$ & Manufacturing & Services & $\begin{array}{l}\text { Primary and } \\
\text { Construction }\end{array}$ & Manufacturing & Services \\
\hline Agriculture, forestry, and fishing & 0.04 & 0.72 & 0.24 & 0.02 & 0.71 & 0.27 \\
\hline Mining & 0.03 & 0.51 & 0.46 & 0.03 & 0.55 & 0.42 \\
\hline Construction & 0.04 & 0.51 & 0.46 & 0.02 & 0.49 & 0.48 \\
\hline Lumber and wood products & 0.54 & 0.24 & 0.22 & 0.48 & 0.24 & 0.28 \\
\hline Furniture and fixtures & 0.10 & 0.64 & 0.26 & 0.04 & 0.68 & 0.28 \\
\hline Stone, clay, and glass products & 0.49 & 0.28 & 0.23 & 0.44 & 0.30 & 0.27 \\
\hline Primary metal industries & 0.15 & 0.67 & 0.18 & 0.10 & 0.69 & 0.22 \\
\hline Fabricated metal products & 0.24 & 0.60 & 0.16 & 0.20 & 0.60 & 0.20 \\
\hline Industrial machinery and equipment & 0.14 & 0.54 & 0.32 & 0.09 & 0.54 & 0.37 \\
\hline Electronic and other electric equipment & 0.16 & 0.53 & 0.31 & 0.11 & 0.51 & 0.38 \\
\hline Transportation equipment & 0.02 & 0.57 & 0.41 & 0.01 & 0.56 & 0.43 \\
\hline Instruments and related products & 0.07 & 0.48 & 0.45 & 0.04 & 0.49 & 0.47 \\
\hline Miscellaneous manufacturing industries & 0.10 & 0.44 & 0.46 & 0.07 & 0.38 & 0.55 \\
\hline Food and kindred products & 0.44 & 0.16 & 0.40 & 0.40 & 0.15 & 0.46 \\
\hline Tobacco products & 0.33 & 0.15 & 0.52 & 0.28 & 0.15 & 0.57 \\
\hline Textile mill products & 0.12 & 0.70 & 0.18 & 0.08 & 0.71 & 0.22 \\
\hline Apparel and other textile products & 0.03 & 0.64 & 0.33 & 0.02 & 0.62 & 0.38 \\
\hline Paper and allied products & 0.06 & 0.60 & 0.34 & 0.03 & 0.56 & 0.40 \\
\hline Printing and publishing & 0.01 & 0.37 & 0.62 & 0.01 & 0.31 & 0.69 \\
\hline Chemicals and allied products & 0.19 & 0.46 & 0.35 & 0.13 & 0.45 & 0.42 \\
\hline Petroleum and coal products & 0.54 & 0.08 & 0.37 & 0.48 & 0.09 & 0.43 \\
\hline Rubber and miscellaneous plastics product & 0.12 & 0.63 & 0.24 & 0.08 & 0.61 & 0.31 \\
\hline Leather and leather products & 0.01 & 0.58 & 0.41 & 0.01 & 0.56 & 0.43 \\
\hline Transportation & 0.13 & 0.52 & 0.35 & 0.08 & 0.43 & 0.49 \\
\hline Communication & 0.09 & 0.18 & 0.73 & 0.03 & 0.19 & 0.78 \\
\hline Electric, gas, and sanitary services & 0.41 & 0.33 & 0.26 & 0.24 & 0.31 & 0.46 \\
\hline Wholesale trade & 0.15 & 0.49 & 0.36 & 0.09 & 0.48 & 0.43 \\
\hline Retail trade & 0.11 & 0.32 & 0.57 & 0.09 & 0.27 & 0.64 \\
\hline Bank and security & 0.26 & 0.17 & 0.58 & 0.17 & 0.13 & 0.69 \\
\hline Insurance & 0.11 & 0.12 & 0.77 & 0.05 & 0.09 & 0.85 \\
\hline Real estate & 0.16 & 0.09 & 0.75 & 0.08 & 0.08 & 0.85 \\
\hline Hotels and other lodging places & 0.10 & 0.27 & 0.63 & 0.04 & 0.25 & 0.71 \\
\hline Personal services & 0.05 & 0.23 & 0.73 & 0.02 & 0.19 & 0.79 \\
\hline Business services & 0.05 & 0.28 & 0.67 & 0.03 & 0.23 & 0.74 \\
\hline Auto repair, services, and parking & 0.09 & 0.39 & 0.51 & 0.04 & 0.32 & 0.64 \\
\hline Miscellaneous repair services & 0.16 & 0.42 & 0.43 & 0.10 & 0.38 & 0.52 \\
\hline Motion pictures & 0.02 & 0.09 & 0.89 & 0.01 & 0.07 & 0.92 \\
\hline Amusement and recreation services & 0.07 & 0.16 & 0.76 & 0.04 & 0.13 & 0.83 \\
\hline Health services & 0.04 & 0.31 & 0.65 & 0.01 & 0.29 & 0.69 \\
\hline Legal services & 0.08 & 0.21 & 0.71 & 0.03 & 0.16 & 0.81 \\
\hline Educational services & 0.32 & 0.15 & 0.53 & 0.14 & 0.13 & 0.73 \\
\hline Other services & 0.22 & 0.17 & 0.61 & 0.15 & 0.15 & 0.70 \\
\hline
\end{tabular}

Note: The each row shows the proportion of an industry's transaction with the primary and construction, the manufacturing, and the services industries. 
Table 3. Parameter Estimates

\begin{tabular}{|c|c|c|}
\hline Parameter & Estimate & Standard Error \\
\hline$\alpha_{L}$ & 0.3591 & 0.0993 \\
\hline$\alpha_{M}$ & 0.7292 & 0.2073 \\
\hline$\alpha_{L M}$ & 0.1007 & 0.0253 \\
\hline$\beta_{N}$ & -0.5984 & 0.0485 \\
\hline$\beta_{O}$ & -0.4202 & 0.3539 \\
\hline$\varphi$ & 0.0235 & 0.0106 \\
\hline$\beta_{N N}$ & 0.2594 & 0.0525 \\
\hline$\beta_{O O}$ & 27.1638 & 6.4814 \\
\hline$\eta$ & 0.9527 & 0.0169 \\
\hline$\beta_{N B}$ & $-2.1846 \mathrm{E}-06$ & $4.8360 \mathrm{E}-07$ \\
\hline$\beta_{N F}$ & $-1.1479 \mathrm{E}-07$ & $7.9158 \mathrm{E}-07$ \\
\hline$\beta_{O B}$ & $-2.4704 \mathrm{E}-05$ & $4.3136 \mathrm{E}-06$ \\
\hline$\beta_{O F}$ & $-7.4049 \mathrm{E}-05$ & $1.0372 \mathrm{E}-05$ \\
\hline Equation & Standard Error & $\mathrm{R}^{2}$ \\
\hline Labor & 0.0148 & 0.9883 \\
\hline Material & 0.0315 & 0.9546 \\
\hline $\begin{array}{l}\text { Non-IT } \\
\text { capital }\end{array}$ & 0.0395 & 0.9967 \\
\hline IT capital & 0.0025 & 0.9864 \\
\hline \multicolumn{2}{|c|}{ Log of likelihood } & 8184 \\
\hline
\end{tabular}

Note: $b_{N O}=\left(\varphi b_{N N} b_{O O}\right)^{\frac{1}{2}}$. Parameter estimates for the industry dummy variables are not reported. 
Table 4. Short-Run Elasticity with respect to IT Spillover Stocks: 42 U.S. Industries, 1984-2000 (Mean Values)

\begin{tabular}{|c|c|c|c|c|c|c|}
\hline Industry & $\varepsilon_{c^{v} S O_{B}}$ & $\varepsilon_{c^{v} S O_{F}}$ & $\varepsilon_{v_{L} S O_{B}}$ & $\varepsilon_{v_{L} S O_{F}}$ & $\varepsilon_{v_{M} S O_{B}}$ & $\varepsilon_{v_{M} S O_{F}}$ \\
\hline Agriculture, forestry, and fishing & $-0.0136^{\mathrm{a}}$ & -0.0013 & $-0.0155^{\mathrm{a}}$ & -0.0014 & $-0.0127^{\mathrm{a}}$ & -0.0012 \\
\hline Mining & $-0.0587^{\mathrm{a}}$ & -0.0037 & $-0.0626^{\mathrm{a}}$ & -0.0040 & $-0.0565^{\mathrm{a}}$ & -0.0036 \\
\hline Construction & $-0.0040^{\mathrm{a}}$ & -0.0015 & $-0.0029^{a}$ & $-0.0011^{\mathrm{a}}$ & $-0.0053^{\mathrm{a}}$ & $-0.0020^{\mathrm{a}}$ \\
\hline Lumber and wood products & $-0.0036^{\mathrm{a}}$ & $-0.0012^{b}$ & $-0.0049^{\mathrm{a}}$ & $-0.0017^{\mathrm{b}}$ & $-0.0030^{\mathrm{a}}$ & $-0.0011^{\mathrm{b}}$ \\
\hline Furniture and fixtures & $-0.0053^{\mathrm{a}}$ & $-0.0005^{\mathrm{a}}$ & $-0.0065^{\mathrm{a}}$ & $-0.0006^{\mathrm{a}}$ & $-0.0048^{\mathrm{a}}$ & $-0.0004^{\mathrm{a}}$ \\
\hline Stone, clay, and glass products & $-0.0050^{\mathrm{a}}$ & $-0.0023^{c}$ & $-0.0058^{\mathrm{a}}$ & $-0.0027^{\mathrm{c}}$ & $-0.0046^{\mathrm{a}}$ & $-0.0021^{\mathrm{c}}$ \\
\hline Primary metal industries & $-0.0077^{\mathrm{a}}$ & -0.0015 & $-0.0133^{\mathrm{a}}$ & -0.0026 & $-0.0061^{\mathrm{a}}$ & -0.0012 \\
\hline Fabricated metal products & $-0.0041^{\mathrm{a}}$ & $-0.0025^{b}$ & $-0.0047^{\mathrm{a}}$ & $-0.0029^{b}$ & $-0.0038^{a}$ & $-0.0022^{b}$ \\
\hline Industrial machinery and equipment & $-0.0113^{\mathrm{a}}$ & $-0.0078^{\mathrm{a}}$ & $-0.0132^{\mathrm{a}}$ & $-0.0097^{\mathrm{a}}$ & $-0.0103^{\mathrm{a}}$ & $-0.0068^{\mathrm{a}}$ \\
\hline Electronic and other electric equipment & $-0.0093^{\mathrm{a}}$ & $-0.0126^{\mathrm{a}}$ & $-0.0104^{\mathrm{a}}$ & $-0.0151^{\mathrm{a}}$ & $-0.0088^{a}$ & $-0.0114^{\mathrm{a}}$ \\
\hline Transportation equipment & $-0.0075^{\mathrm{a}}$ & $-0.0009^{b}$ & $-0.0119^{\mathrm{a}}$ & $-0.0014^{\mathrm{b}}$ & $-0.0061^{\mathrm{a}}$ & $-0.0007^{\mathrm{b}}$ \\
\hline Instruments and related products & $-0.0110^{\mathrm{a}}$ & $-0.0067^{\mathrm{a}}$ & $-0.0126^{\mathrm{a}}$ & $-0.0079^{\mathrm{a}}$ & $-0.0101^{\mathrm{a}}$ & $-0.0061^{\mathrm{a}}$ \\
\hline Miscellaneous manufacturing industries & $-0.0086^{\mathrm{a}}$ & $-0.0042^{\mathrm{a}}$ & $-0.0091^{\mathrm{a}}$ & $-0.0046^{\mathrm{a}}$ & $-0.0082^{\mathrm{a}}$ & $-0.0040^{\mathrm{a}}$ \\
\hline Food and kindred products & $-0.0049^{\mathrm{a}}$ & $-0.0017^{\mathrm{c}}$ & $-0.0124^{\mathrm{a}}$ & $-0.0044^{\mathrm{c}}$ & $-0.0035^{\mathrm{a}}$ & $-0.0012^{\mathrm{c}}$ \\
\hline Tobacco products & $-0.0110^{\mathrm{a}}$ & $-0.0002^{b}$ & $-0.0418^{\mathrm{a}}$ & $-0.0007^{\mathrm{b}}$ & $-0.0077^{\mathrm{a}}$ & $-0.0001^{b}$ \\
\hline Textile mill products & $-0.0054^{\mathrm{a}}$ & $-0.0022^{c}$ & $-0.0082^{\mathrm{a}}$ & $-0.0033^{\mathrm{c}}$ & $-0.0045^{\mathrm{a}}$ & $-0.0017^{\mathrm{c}}$ \\
\hline Apparel and other textile products & $-0.0041^{\mathrm{a}}$ & $-0.0010^{\mathrm{a}}$ & $-0.0056^{\mathrm{a}}$ & $-0.0014^{\mathrm{a}}$ & $-0.0035^{\mathrm{a}}$ & $-0.0008^{a}$ \\
\hline Paper and allied products & $-0.0065^{\mathrm{a}}$ & -0.0041 & $-0.0105^{\mathrm{a}}$ & -0.0067 & $-0.0053^{\mathrm{a}}$ & -0.0033 \\
\hline Printing and publishing & $-0.0112^{\mathrm{a}}$ & $-0.0207^{\mathrm{a}}$ & $-0.0121^{\mathrm{a}}$ & $-0.0226^{\mathrm{a}}$ & $-0.0107^{\mathrm{a}}$ & $-0.0196^{\mathrm{a}}$ \\
\hline Chemicals and allied products & $-0.0111^{\mathrm{a}}$ & $-0.0025^{\mathrm{b}}$ & $-0.0176^{\mathrm{a}}$ & $-0.0040^{\mathrm{b}}$ & $-0.0089^{\mathrm{a}}$ & $-0.0020^{\mathrm{b}}$ \\
\hline Petroleum and coal products & $-0.0049^{\mathrm{a}}$ & -0.0007 & $-0.0264^{\mathrm{a}}$ & -0.0039 & $-0.0032^{\mathrm{a}}$ & -0.0005 \\
\hline Rubber and miscellaneous plastics product & $-0.0035^{\mathrm{a}}$ & $-0.0027^{b}$ & $-0.0050^{\mathrm{a}}$ & $-0.0040^{\mathrm{b}}$ & $-0.0029^{a}$ & $-0.0023^{b}$ \\
\hline Leather and leather products & $-0.0061^{\mathrm{a}}$ & $-0.0017^{b}$ & $-0.0064^{\mathrm{a}}$ & $-0.0019^{b}$ & $-0.0059^{a}$ & $-0.0016^{\mathrm{b}}$ \\
\hline Transportation & $-0.0208^{\mathrm{a}}$ & -0.0055 & $-0.0193^{\mathrm{a}}$ & -0.0051 & $-0.0221^{\mathrm{a}}$ & -0.0057 \\
\hline Communication & $-0.0388^{\mathrm{a}}$ & $-0.0325^{\mathrm{c}}$ & $-0.0434^{\mathrm{a}}$ & $-0.0383^{c}$ & $-0.0370^{\mathrm{a}}$ & $-0.0299^{c}$ \\
\hline Electric, gas, and sanitary services & $-0.0362^{\mathrm{a}}$ & -0.0173 & $-0.0475^{\mathrm{a}}$ & -0.0227 & $-0.0314^{\mathrm{a}}$ & -0.0150 \\
\hline Wholesale trade & $-0.0170^{\mathrm{a}}$ & $-0.0219^{a}$ & $-0.0120^{\mathrm{a}}$ & $-0.0156^{\mathrm{a}}$ & $-0.0236^{\mathrm{a}}$ & $-0.0302^{\mathrm{a}}$ \\
\hline Retail trade & $-0.0179^{\mathrm{a}}$ & $-0.0030^{\mathrm{a}}$ & $-0.0126^{\mathrm{a}}$ & $-0.0021^{\mathrm{a}}$ & $-0.0245^{\mathrm{a}}$ & $-0.0041^{\mathrm{a}}$ \\
\hline Bank and security & $-0.0331^{\mathrm{a}}$ & $-0.0389^{\mathrm{a}}$ & $-0.0263^{\mathrm{a}}$ & $-0.0311^{\mathrm{a}}$ & $-0.0404^{\mathrm{a}}$ & $-0.0472^{\mathrm{a}}$ \\
\hline $\begin{array}{l}\text { Insurance } \\
\text { In }\end{array}$ & $-0.0276^{\mathrm{a}}$ & $-0.0195^{\mathrm{a}}$ & $-0.0238^{\mathrm{a}}$ & $-0.0168^{\mathrm{a}}$ & $-0.0309^{\mathrm{a}}$ & $-0.0219^{\mathrm{a}}$ \\
\hline Real estate & $-0.0453^{\mathrm{a}}$ & -0.0841 & $-0.0783^{\mathrm{a}}$ & -0.1502 & $-0.0358^{\mathrm{a}}$ & -0.0652 \\
\hline Hotels and other lodging places & $-0.0278^{\mathrm{a}}$ & -0.0060 & $-0.0217^{\mathrm{a}}$ & -0.0048 & $-0.0338^{a}$ & -0.0073 \\
\hline Personal services & $-0.0090^{\mathrm{a}}$ & $-0.0021^{b}$ & $-0.0068^{\mathrm{a}}$ & $-0.0016^{\mathrm{b}}$ & $-0.0116^{\mathrm{a}}$ & $-0.0026^{\mathrm{b}}$ \\
\hline Business services & $-0.0062^{\mathrm{a}}$ & $-0.0665^{\mathrm{a}}$ & $-0.0040^{\mathrm{a}}$ & $-0.0432^{\mathrm{a}}$ & $-0.0099^{\mathrm{a}}$ & $-0.1068^{\mathrm{a}}$ \\
\hline Auto repair, services, and parking & $-0.0142^{\mathrm{a}}$ & -0.0051 & $-0.0120^{\mathrm{a}}$ & -0.0043 & $-0.0161^{\mathrm{a}}$ & -0.0057 \\
\hline Miscellaneous repair services & $-0.0030^{\mathrm{a}}$ & $-0.0098^{\mathrm{a}}$ & $-0.0035^{\mathrm{a}}$ & $-0.0119^{\mathrm{a}}$ & $-0.0028^{\mathrm{a}}$ & $-0.0089^{\mathrm{a}}$ \\
\hline Motion pictures & $-0.0208^{\mathrm{a}}$ & $-0.0122^{\mathrm{a}}$ & $-0.0196^{\mathrm{a}}$ & $-0.0116^{\mathrm{a}}$ & $-0.0217^{\mathrm{a}}$ & $-0.0127^{\mathrm{a}}$ \\
\hline Amusement and recreation services & $-0.0139^{\mathrm{a}}$ & -0.0021 & $-0.0117^{\mathrm{a}}$ & -0.0018 & $-0.0157^{\mathrm{a}}$ & -0.0024 \\
\hline Health services & $-0.0088^{\mathrm{a}}$ & $0.0000^{\mathrm{a}}$ & $-0.0050^{\mathrm{a}}$ & $0.0000^{\mathrm{a}}$ & $-0.0165^{\mathrm{a}}$ & $0.0000^{\mathrm{a}}$ \\
\hline Legal services & $-0.0049^{\mathrm{a}}$ & $-0.0263^{\mathrm{a}}$ & $-0.0030^{\mathrm{a}}$ & $-0.0163^{\mathrm{a}}$ & $-0.0088^{a}$ & $-0.0464^{\mathrm{a}}$ \\
\hline Educational services & $-0.0422^{\mathrm{a}}$ & $-0.0029^{\mathrm{a}}$ & $-0.0293^{\mathrm{a}}$ & $-0.0020^{\mathrm{a}}$ & $-0.0584^{\mathrm{a}}$ & $-0.0040^{\mathrm{a}}$ \\
\hline Other services & $-0.0093^{\mathrm{a}}$ & $-0.0215^{\mathrm{a}}$ & $-0.0068^{\mathrm{a}}$ & $-0.0159^{\mathrm{a}}$ & $-0.0121^{\mathrm{a}}$ & $-0.0279^{\mathrm{a}}$ \\
\hline Manufacturing & -0.0076 & -0.0045 & -0.0121 & -0.0061 & -0.0064 & -0.0040 \\
\hline Services & -0.0228 & -0.0251 & -0.0223 & -0.0254 & -0.0262 & -0.0299 \\
\hline Total & -0.0166 & -0.0154 & -0.0179 & -0.0162 & -0.0181 & -0.0179 \\
\hline
\end{tabular}

Note: The services sector excludes not only the manufacturing sector but also agriculture, forestry, and fishing, mining, and construction industries.

a: Significant at the $1 \%$ level.

${ }^{b}$ : Significant at the $5 \%$ level.

c: Significant at the $10 \%$ level. 


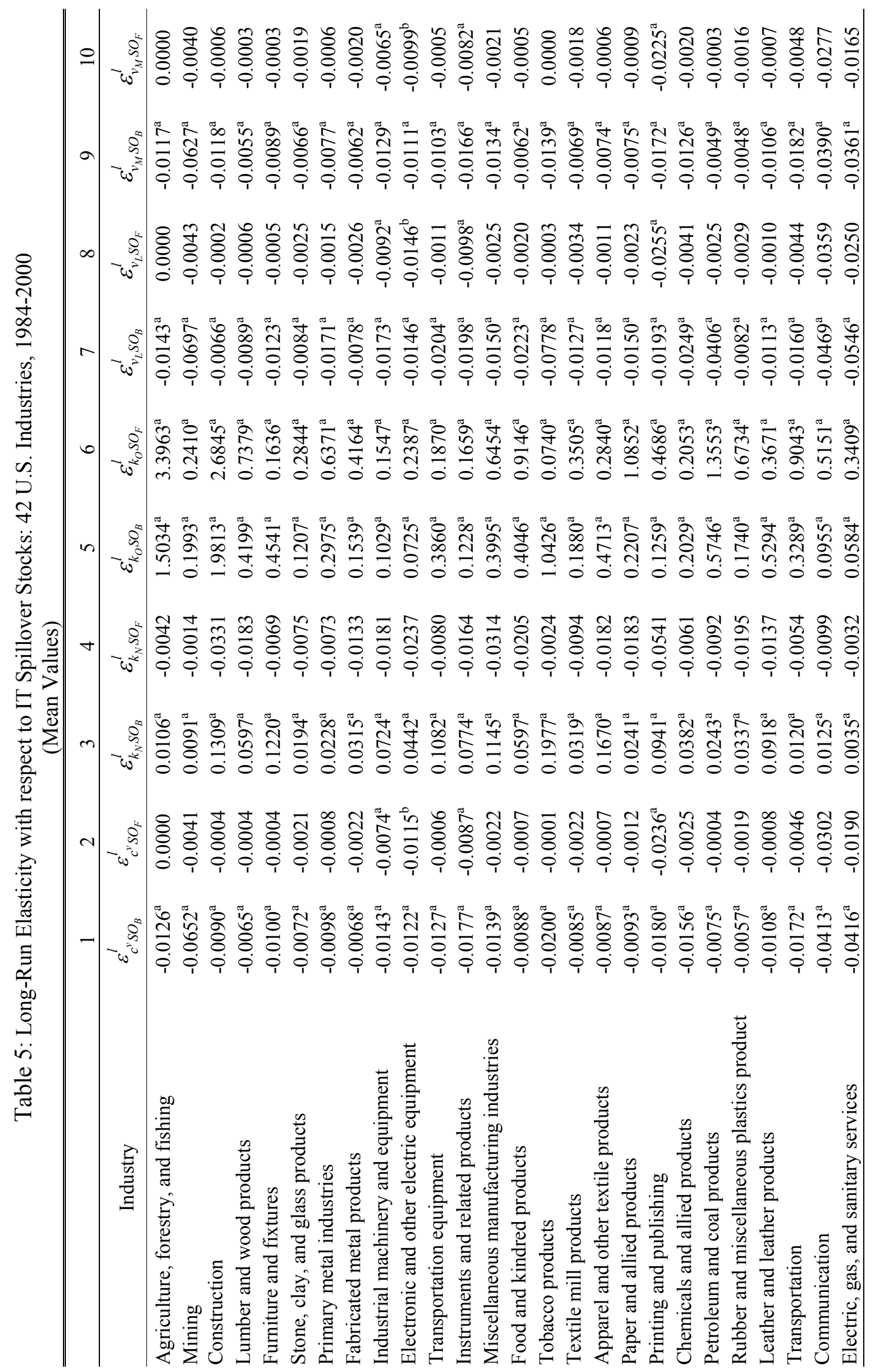




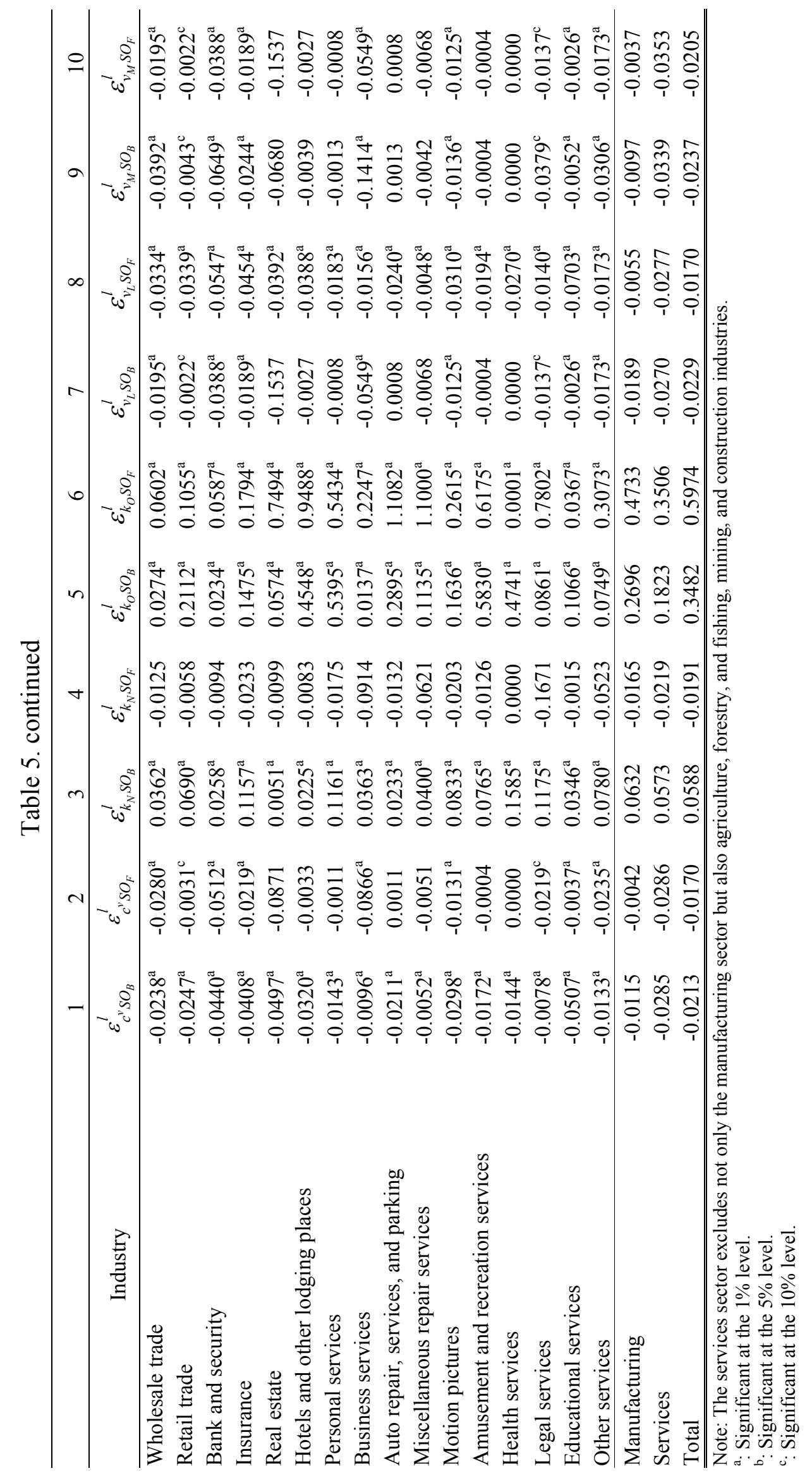




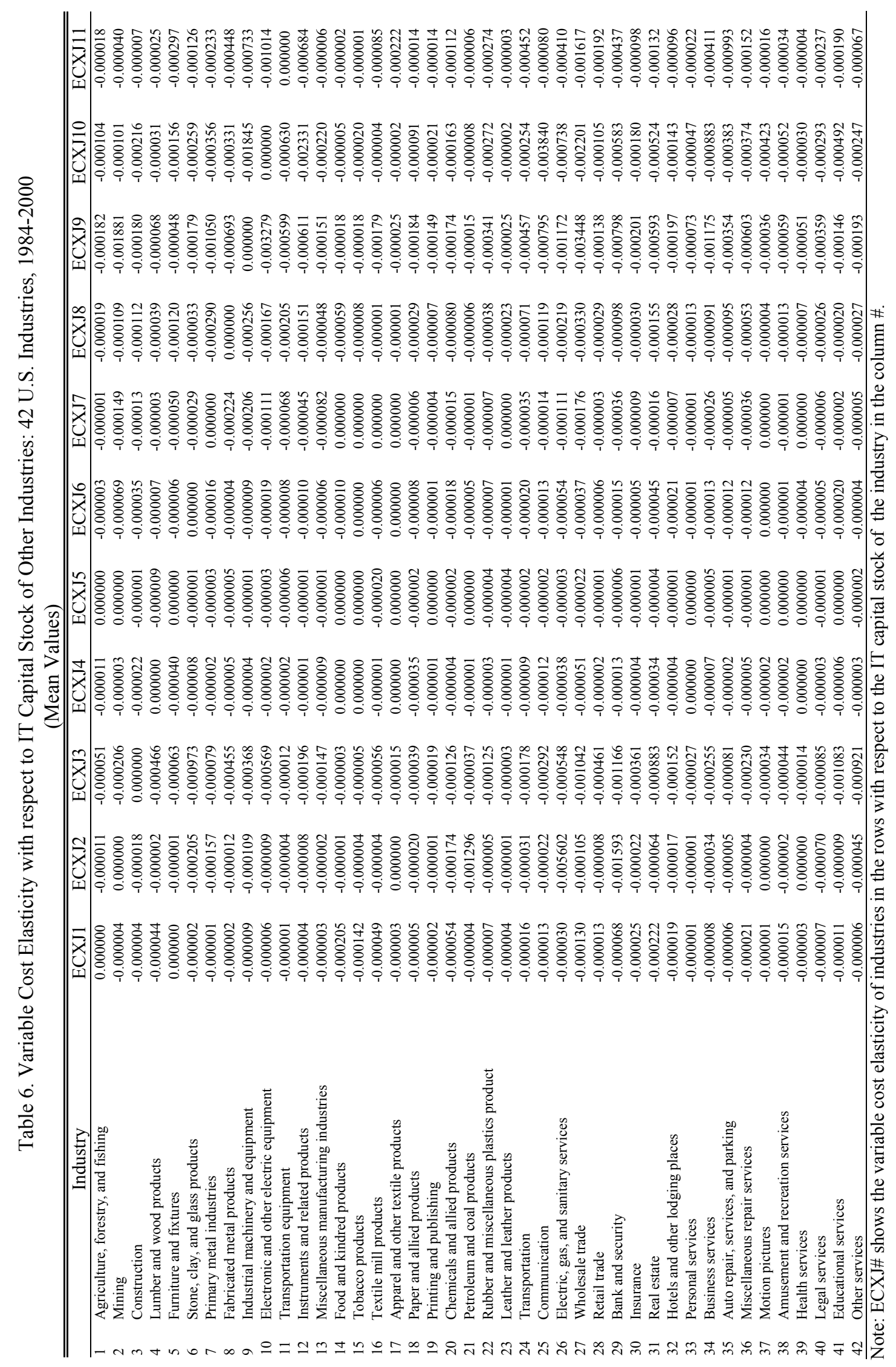




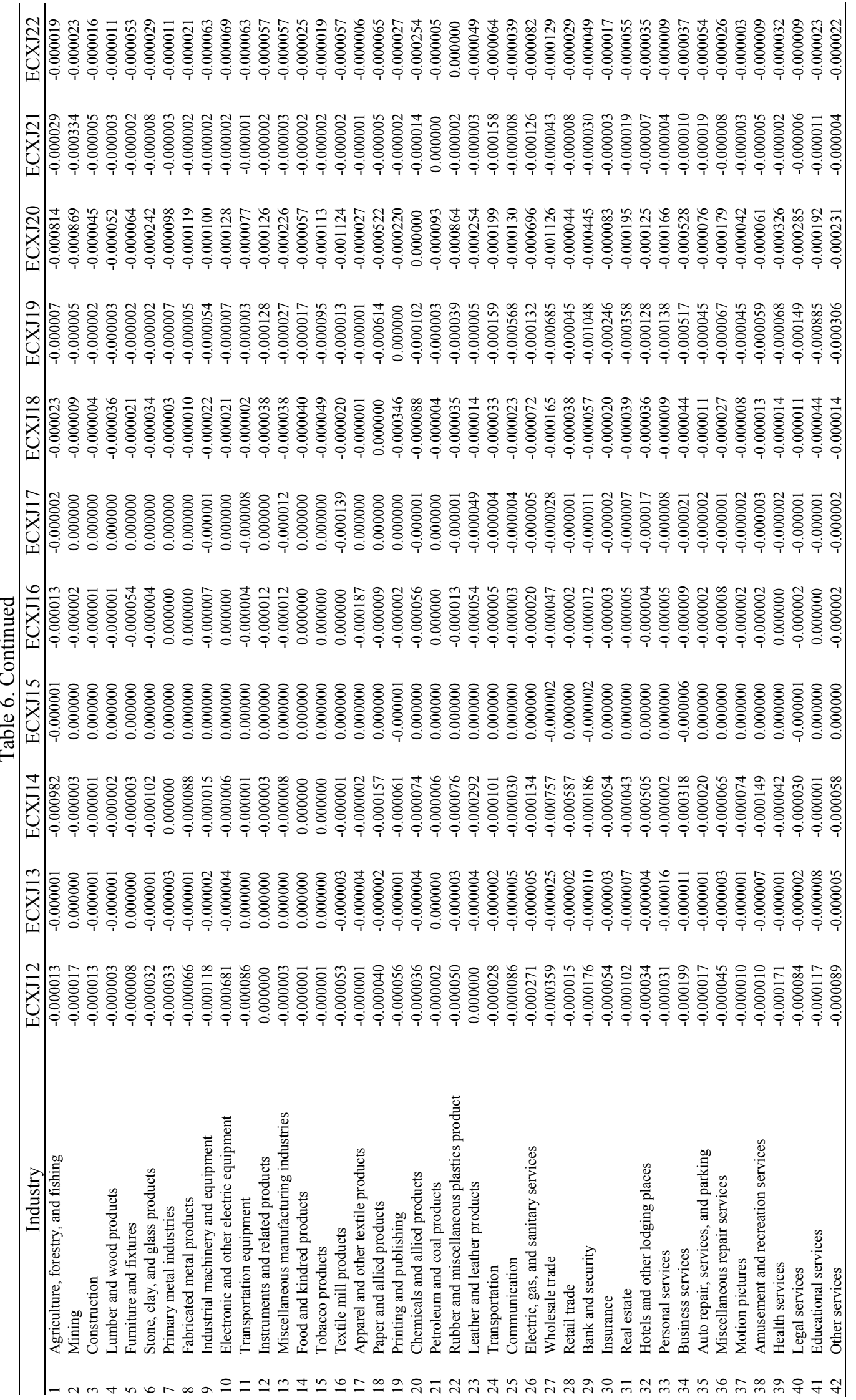




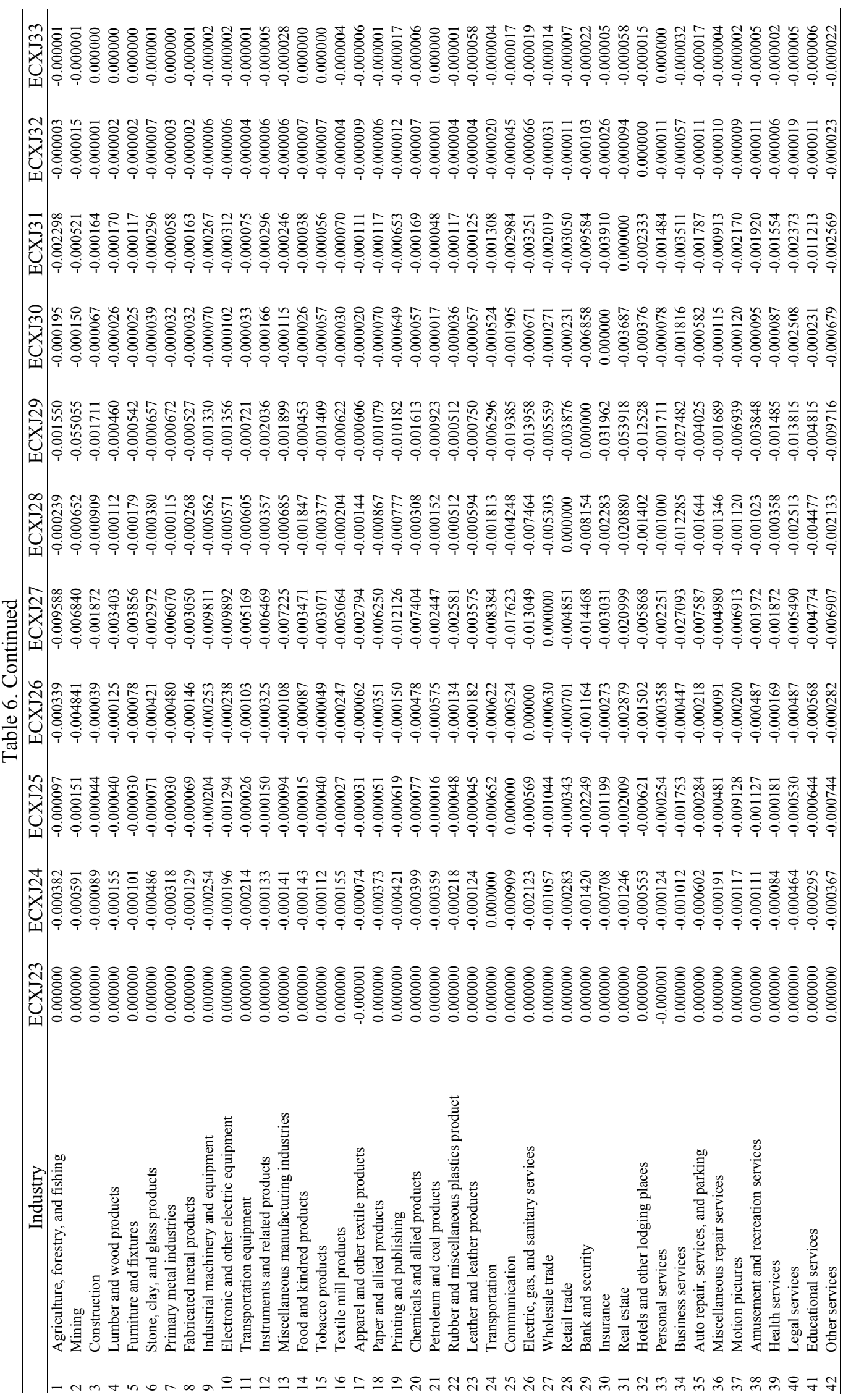




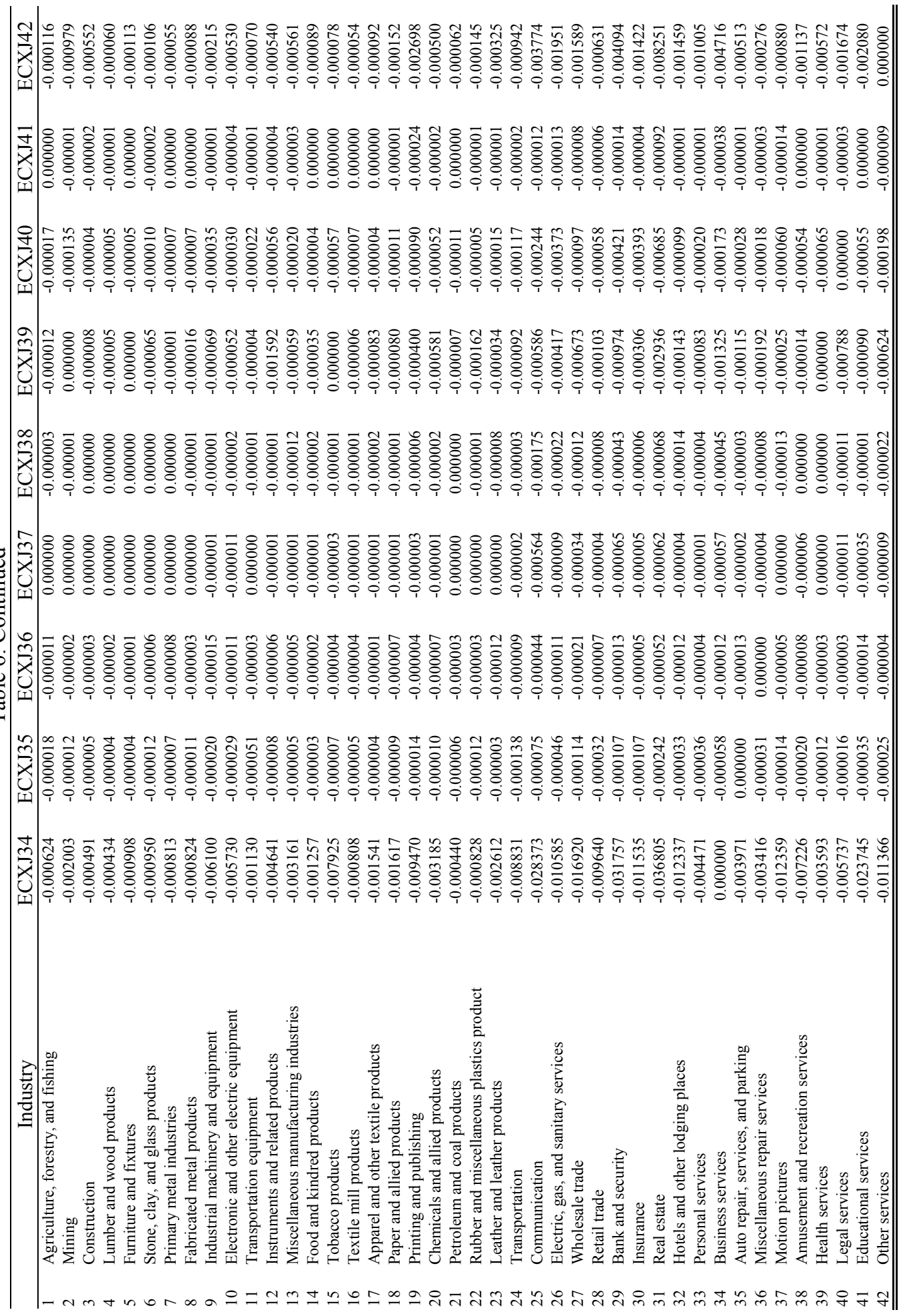




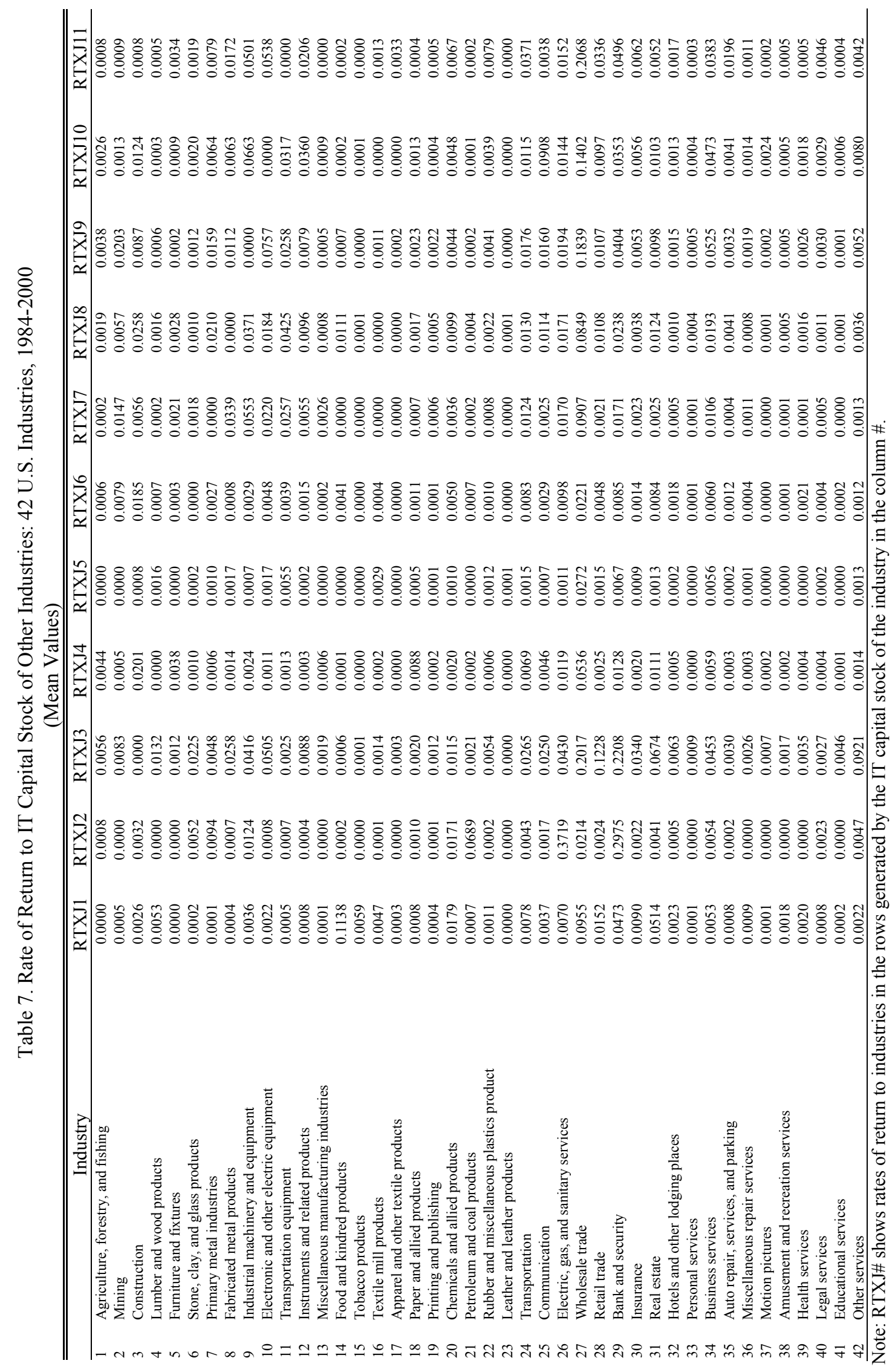




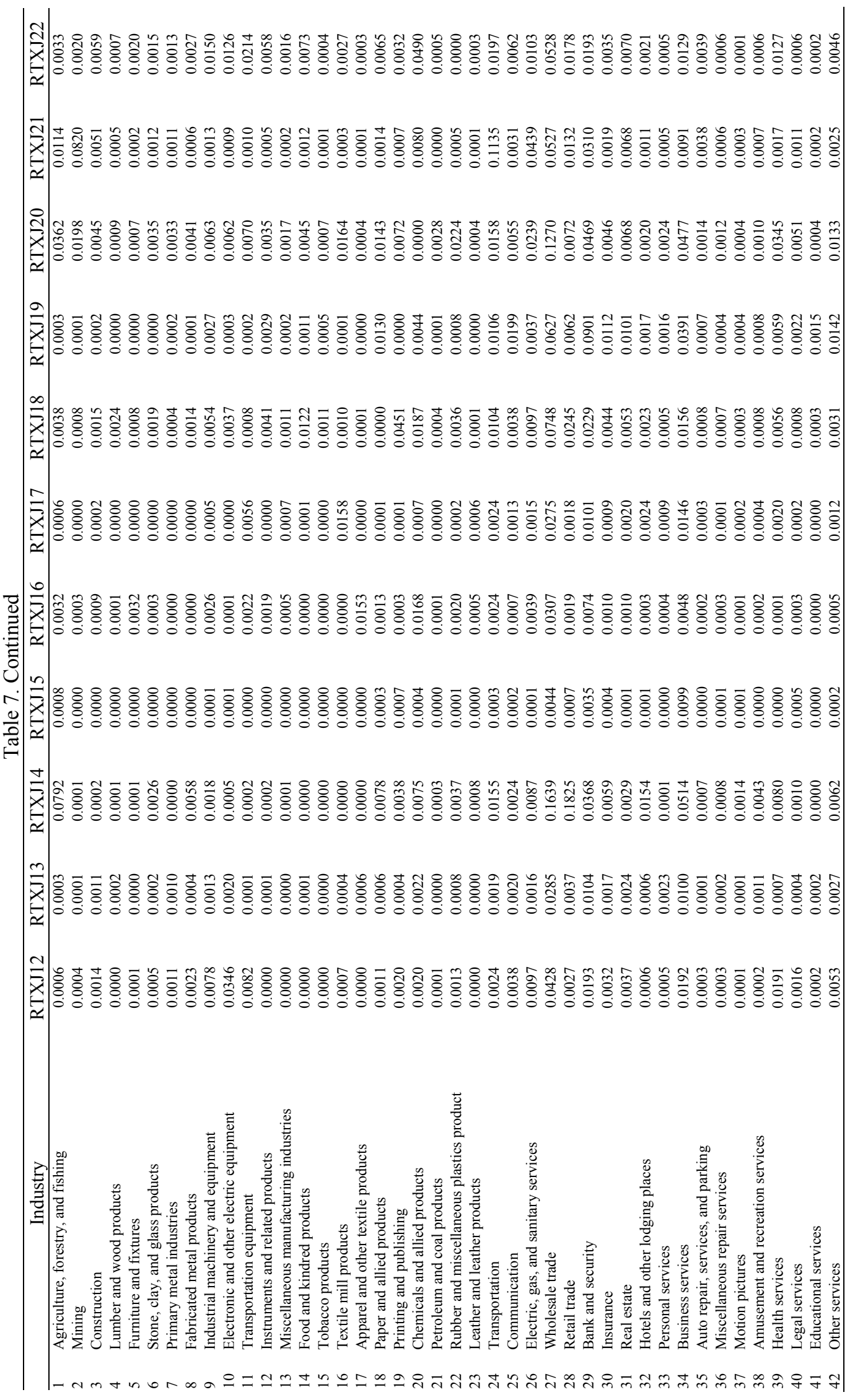




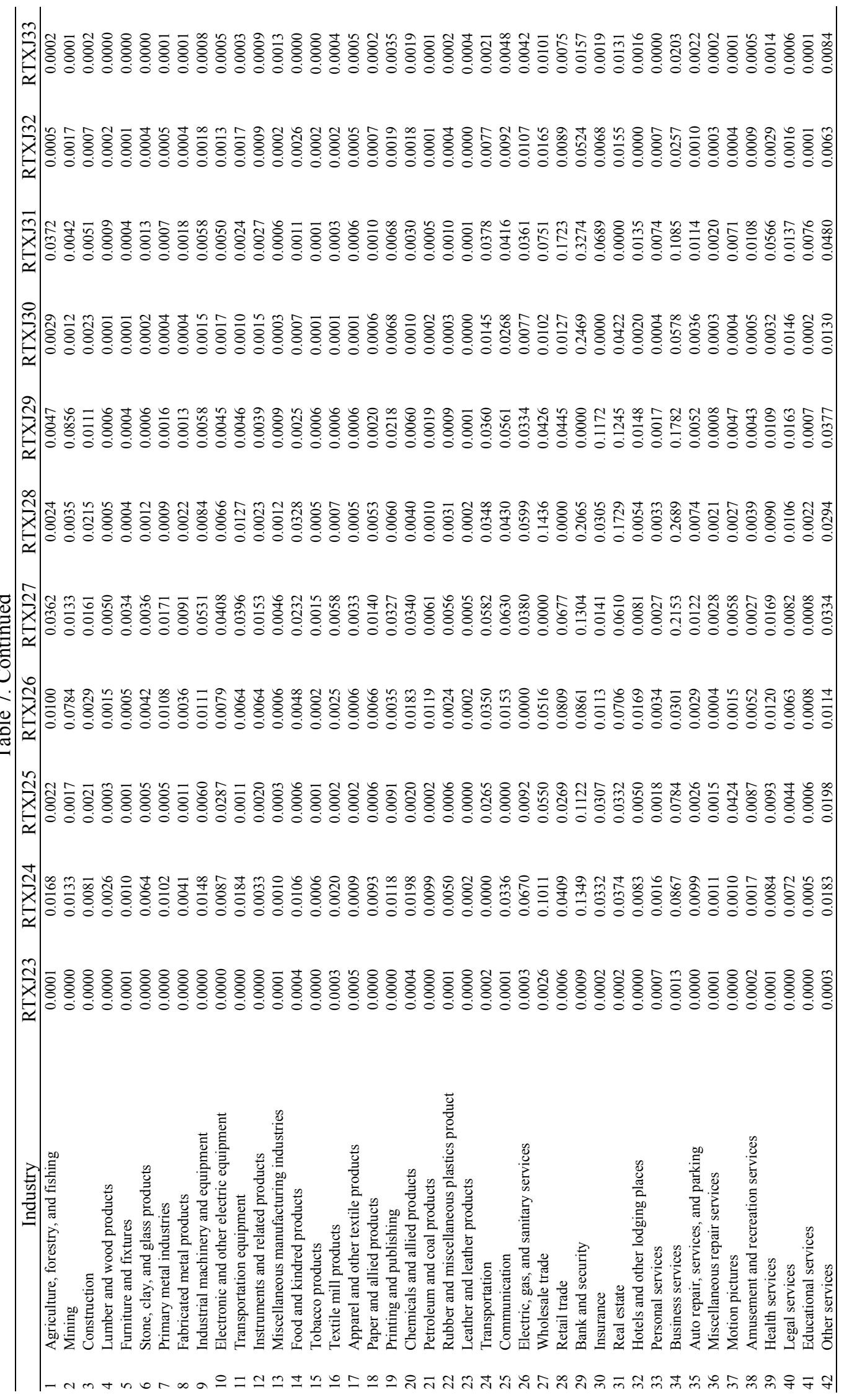




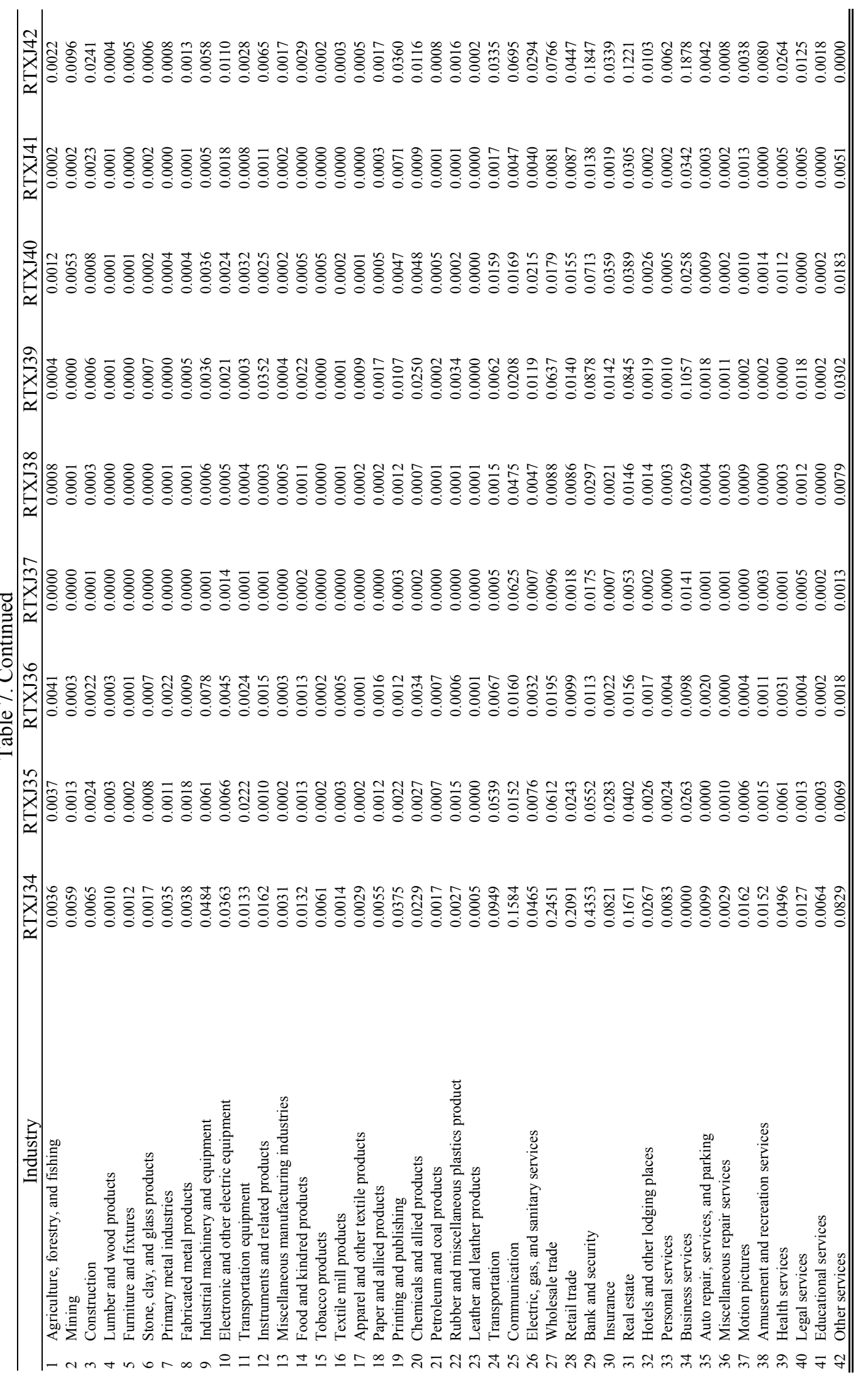


Table 8: Average Rate of Return Received and Generated from IT Capital Stock: 42 U.S. Industries, 1984-2000

\begin{tabular}{lcc}
\hline \hline \multicolumn{1}{c}{ Industry } & $\begin{array}{c}\text { Average } \\
\text { return } \\
\text { received }\end{array}$ & $\begin{array}{c}\text { Average } \\
\text { return } \\
\text { generated }\end{array}$ \\
\hline Agriculture, forestry, and fishing & 0.007 & 0.010 \\
Mining & 0.010 & 0.020 \\
Construction & 0.006 & 0.027 \\
Lumber and wood products & 0.001 & 0.004 \\
Furniture and fixtures & 0.001 & 0.002 \\
Stone, clay, and glass products & 0.002 & 0.003 \\
Primary metal industries & 0.003 & 0.008 \\
Fabricated metal products & 0.004 & 0.010 \\
Industrial machinery and equipment & 0.012 & 0.014 \\
Electronic and other electric equipment & 0.011 & 0.014 \\
Transportation equipment & 0.008 & 0.015 \\
Instruments and related products & 0.005 & 0.005 \\
Miscellaneous manufacturing industries & 0.001 & 0.002 \\
Food and kindred products & 0.006 & 0.015 \\
Tobacco products & 0.000 & 0.001 \\
Textile mill products & 0.002 & 0.003 \\
Apparel and other textile products & 0.001 & 0.002 \\
Paper and allied products & 0.003 & 0.007 \\
Printing and publishing & 0.007 & 0.008 \\
Chemicals and allied products & 0.009 & 0.013 \\
Petroleum and coal products & 0.003 & 0.010 \\
Rubber and miscellaneous plastics product & 0.002 & 0.008 \\
Leather and leather products & 0.000 & 0.000 \\
Transportation & 0.020 & 0.019 \\
Communication & 0.022 & 0.013 \\
Electric, gas, and sanitary services & 0.025 & 0.016 \\
Wholesale trade & 0.069 & 0.027 \\
Retail trade & 0.031 & 0.028 \\
Bank and security & 0.080 & 0.022 \\
Insurance & 0.015 & 0.012 \\
Real estate & 0.032 & 0.028 \\
Hotels and other lodging places & 0.004 & 0.005 \\
Personal services & 0.001 & 0.003 \\
Business services & 0.048 & 0.047 \\
Auto repair, services, and parking & 0.003 & 0.010 \\
Miscellaneous repair services & 0.001 & 0.003 \\
Motion pictures & 0.002 & 0.003 \\
Amusement and recreation services & 0.002 & 0.004 \\
Health services & 0.008 & 0.013 \\
Legal services & 0.004 & 0.008 \\
Educational services & 0.001 & 0.003 \\
Other services & 0.014 & 0.024 \\
\hline Ste The & & \\
& &
\end{tabular}

Note: The rates of returns are the mean values over 1984-2000. The returns do not include returns to own IT capital. 
Table 9. Decomposition of Total Factor Productivity: 42 U.S. Industries, 1985-2000

\begin{tabular}{|c|c|c|c|c|c|}
\hline & $\begin{array}{c}\text { TFP } \\
\text { Growth }\end{array}$ & $\begin{array}{l}\text { Scale } \\
\text { Effect }\end{array}$ & $\begin{array}{c}\text { Contributic } \\
\text { of } S O_{B}\end{array}$ & $\begin{array}{l}\text { Contribution } \\
\text { of } S O_{F}\end{array}$ & Residuals \\
\hline Agriculture, forestry, and fishing & 0.0160 & 0.0104 & 0.0020 & 0.0002 & 0.0032 \\
\hline Mining & 0.0084 & -0.0037 & 0.0070 & 0.0002 & 0.0037 \\
\hline Construction & -0.0008 & 0.0008 & 0.0008 & 0.0003 & -0.0027 \\
\hline Lumber and wood products & -0.0022 & 0.0008 & 0.0007 & 0.0002 & -0.0040 \\
\hline Furniture and fixtures & 0.0012 & 0.0018 & 0.0010 & 0.0001 & -0.0018 \\
\hline Stone, clay, and glass products & 0.0091 & 0.0010 & 0.0009 & 0.0004 & 0.0067 \\
\hline Primary metal industries & 0.0088 & 0.0013 & 0.0013 & 0.0002 & 0.0058 \\
\hline Fabricated metal products & 0.0056 & 0.0009 & 0.0007 & 0.0004 & 0.0034 \\
\hline Industrial machinery and equipment & 0.0345 & 0.0062 & 0.0019 & 0.0016 & 0.0242 \\
\hline Electronic and other electric equipment & 0.0569 & 0.0084 & 0.0016 & 0.0024 & 0.0440 \\
\hline Transportation equipment & -0.0002 & 0.0017 & 0.0013 & 0.0001 & -0.0036 \\
\hline Instruments and related products & -0.0071 & 0.0012 & 0.0018 & 0.0011 & -0.0116 \\
\hline Miscellaneous manufacturing industries & 0.0101 & 0.0012 & 0.0014 & 0.0009 & 0.0062 \\
\hline Food and kindred products & 0.0002 & 0.0010 & 0.0009 & 0.0003 & -0.0022 \\
\hline Tobacco products & -0.0449 & -0.0006 & 0.0022 & 0.0001 & -0.0469 \\
\hline Textile mill products & 0.0082 & 0.0005 & 0.0010 & 0.0004 & 0.0062 \\
\hline Apparel and other textile products & 0.0076 & 0.0003 & 0.0007 & 0.0003 & 0.0062 \\
\hline Paper and allied products & -0.0015 & 0.0009 & 0.0012 & 0.0007 & -0.0045 \\
\hline Printing and publishing & -0.0113 & 0.0006 & 0.0022 & 0.0040 & -0.0195 \\
\hline Chemicals and allied products & 0.0119 & 0.0015 & 0.0020 & 0.0004 & 0.0077 \\
\hline Petroleum and coal products & 0.0027 & 0.0010 & 0.0007 & 0.0001 & 0.0008 \\
\hline Rubber and miscellaneous plastics product & 0.0114 & 0.0026 & 0.0006 & 0.0005 & 0.0075 \\
\hline Leather and leather products & 0.0080 & -0.0013 & 0.0008 & 0.0006 & 0.0077 \\
\hline Transportation & 0.0132 & 0.0156 & 0.0041 & 0.0013 & -0.0085 \\
\hline Communication & 0.0101 & 0.0110 & 0.0078 & 0.0067 & -0.0175 \\
\hline Electric, gas, and sanitary services & 0.0056 & -0.0068 & 0.0042 & 0.0019 & 0.0056 \\
\hline Wholesale trade & 0.0156 & -0.0022 & 0.0033 & 0.0037 & 0.0096 \\
\hline Retail trade & 0.0079 & 0.0026 & 0.0032 & 0.0006 & 0.0010 \\
\hline Bank and security & 0.0021 & -0.0097 & 0.0065 & 0.0053 & -0.0021 \\
\hline Insurance & -0.0082 & 0.0005 & 0.0056 & 0.0043 & -0.0206 \\
\hline Real estate & -0.0021 & 0.0045 & 0.0057 & 0.0093 & -0.0243 \\
\hline Hotels and other lodging places & -0.0052 & 0.0014 & 0.0042 & 0.0010 & -0.0124 \\
\hline Personal services & -0.0017 & 0.0026 & 0.0017 & 0.0003 & -0.0068 \\
\hline Business services & -0.0038 & -0.0022 & 0.0011 & 0.0109 & -0.0156 \\
\hline Auto repair, services, and parking & -0.0088 & 0.0006 & 0.0024 & 0.0008 & -0.0129 \\
\hline Miscellaneous repair services & -0.0246 & 0.0023 & 0.0005 & 0.0019 & -0.0297 \\
\hline Motion pictures & -0.0162 & 0.0024 & 0.0048 & 0.0020 & -0.0265 \\
\hline Amusement and recreation services & 0.0006 & 0.0067 & 0.0027 & 0.0003 & -0.0096 \\
\hline Health services & -0.0094 & 0.0032 & 0.0018 & 0.0000 & -0.0146 \\
\hline Legal services & -0.0152 & 0.0025 & 0.0010 & 0.0051 & -0.0250 \\
\hline Educational services & -0.0067 & 0.0017 & 0.0085 & 0.0005 & -0.0189 \\
\hline Other services & -0.0044 & 0.0038 & 0.0020 & 0.0041 & -0.0155 \\
\hline
\end{tabular}



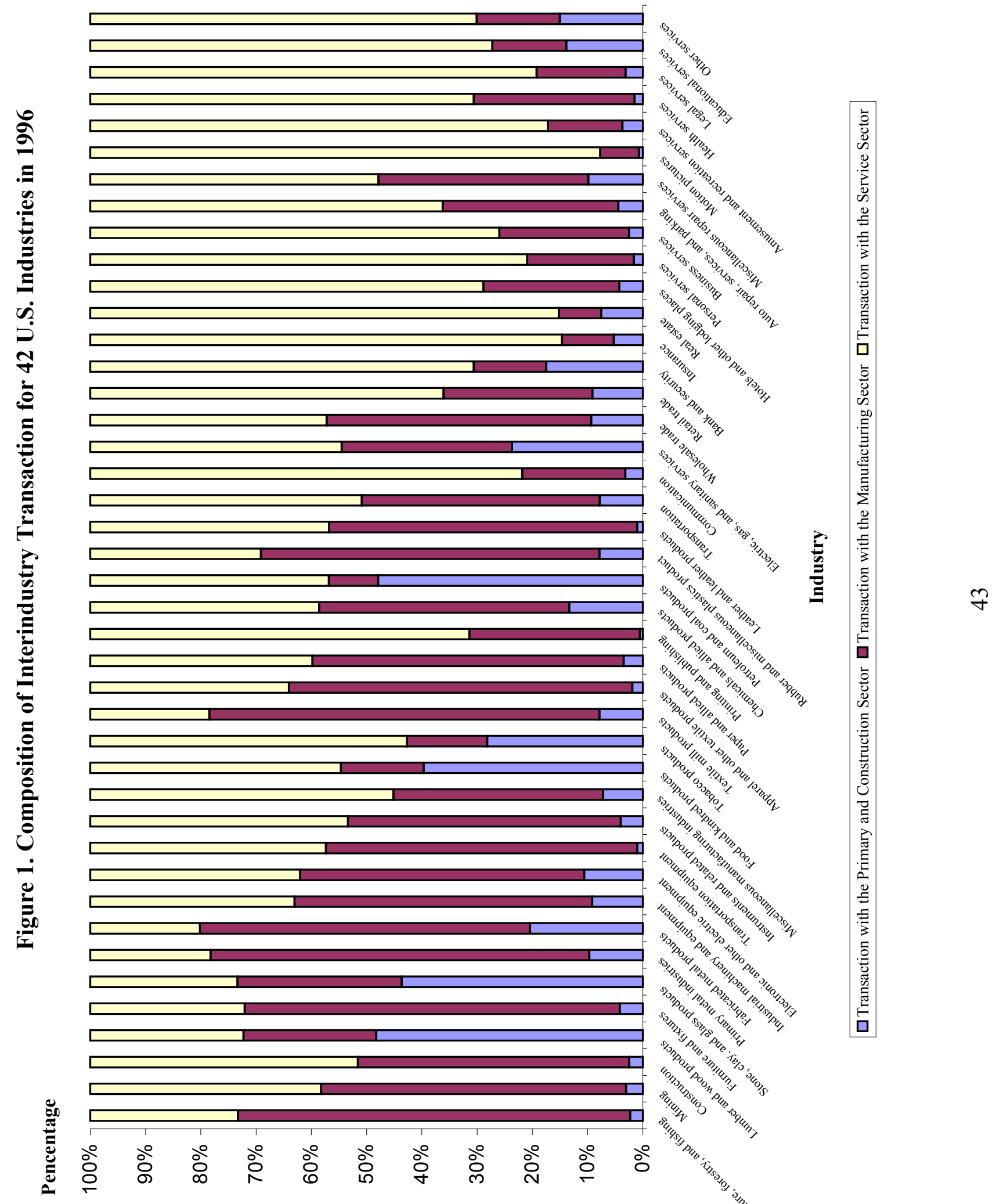